Indonesian Journal of Theology 4/1 (July 2016): 1-44

\title{
SEBUAH UPAYA PEMBACAAN POSKOLONIAL DENGAN METODE DIALOG IMAJINATIF ANTARA FOTO SOEHARTO “PIYE KABARE, PENAK JAMANKU TO?" DAN TEKS KELUARAN 14:10-12; 16:1-3; 17:3
}

\author{
Angela Pontororing
}

\begin{abstract}
Around year 2013, Soeharto's meme "Piye kabare, penak jamanku to?" was heavily distributed around society in many form, such as stickers, t-shirts and also in internet. Even though New Order regime can be said as a regime colored with violence and oppression, Indonesian civilians still showing intention to bring back the New Order system rather than living in the crisis they're facing at that time. The same symptoms can be seen in the exodus narration of the Israeli from Egypt. In the time of crisis, the Israeli cried their wish to go back to slavery in Egypt. To build a contextual theology that is more sensitive to actual socio-political issues, these symptoms need to be studied further. Therefore, this article uses postcolonial perspective to read two texts which were born from two different contexts. Dialogical imagination was chosen as a method to draw these three things together in one critical analytical reading.
\end{abstract}

Keywords: Soeharto's meme, Exodus, Postcolonial theory, dialogical imagination, New Order, Slavery, Postcolonial limbo, Contextual theology.

\begin{abstract}
Abstrak
Sekitar tahun 2013, foto Soeharto bertajuk "Piye kabare, penak jamanku to?" marak beredar di masyarakat baik dalam bentuk sticker, kaos dan juga beredar di internet. Meskipun era Orde Baru bisa dianggap sebagai rezim yang diwarnai kekerasan dan penindasan, masyarakat tetap menunjukkan keinginan untuk mengembalikan sistem pemerintahan Orde Baru dibandingkan dengan krisis yang sedang dihadapi saat ini. Gejala yang sama terlihat dari narasi keluarnya bangsa Israel dari Mesir. Pada saat-saat krisis, bangsa Israel beberapa kali menyerukan keinginan untuk kembali kepada perbudakan di Mesir. Penulis merasa gejala ini
\end{abstract}


perlu untuk dianalisa lebih lanjut untuk membangun sebuah teologi kontekstual yang semakin peka pada isu-isu sosial politik yang aktual di masyarakat. Untuk itu, dalam tulisan ini penulis menggunakan perspektif poskolonial untuk membaca kedua teks yang lahir dari dua konteks yang berbeda. Metode dialog imajinatif dipilih sebagai cara untuk mempertemukan ketiga hal ini dalam satu pembacaan yang analitis kritis.

Kata-Kata Kunci: Foto Soeharto, Keluaran, Teori Poskolonial, Dialog Imajinatif, Orde Baru, Perbudakan, Reformasi, Limbo Poskolonial, Teologi Kontekstual.

\section{Pendahuluan}

Pada tahun 2013, lima belas tahun setelah era Reformasi dimulai, Indonesia sudah mengalami empat kali pergantian presiden. Namun perubahan yang terjadi sepertinya belum memenuhi harapan masyarakat. Sampai saat itu, perekonomian di Indonesia masih tidak stabil. Ditambah lagi, kenaikan harga BBM (Bahan Bakar Minyak) pada tanggal 22 Juni 2013 melambungkan harga kebutuhan lainnya dan mengguncang perekonomian rakyat. Masyarakat bahkan semakin kehilangan kepercayaan kepada badan hukum dan pemerintah, dikarenakan berbagai kasus korupsi dan penyimpangan hukum yang terjadi. Indonesia masih terombang-ambing dalam berbagai krisis, termasuk krisis kepemimpinan. Sepertinya belum ada sosok pemimpin yang mampu membawa Indonesia keluar dari krisis yang berkepanjangan.

Dalam kondisi yang demikian, muncul sebuah fenomena yang cukup menarik perhatian masyarakat. Entah dari mana, mulai bermunculan sticker-sticker, spanduk dan bahkan foto-foto yang beredar di Internet yang memajang foto mantan presiden Soeharto sedang tersenyum dan bertanya dalam bahasa jawa ngoko, "piye kabare le, penak jamanku toh?" (bagaimana kabarnya nak, lebih enak jamanku kan?). 


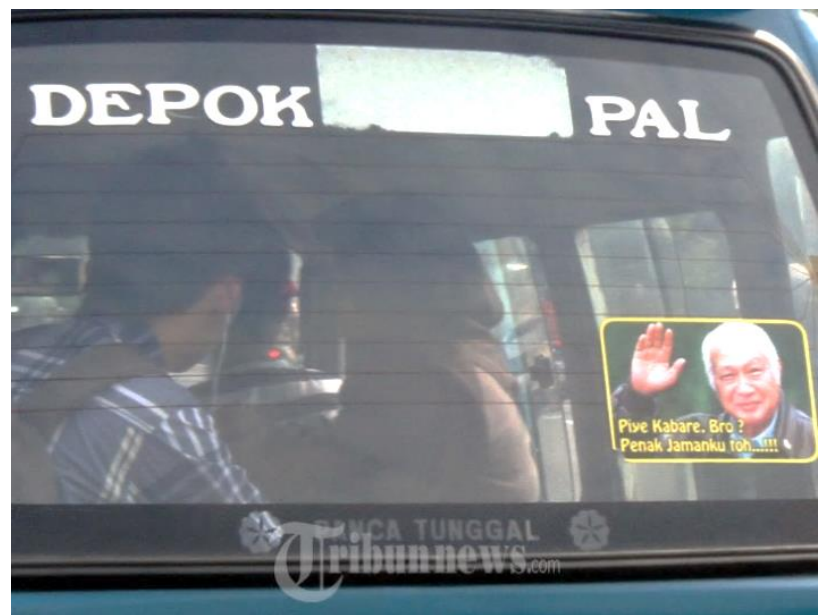

Gambar 1. Sticker Foto Soeharto di kendaraan umum masuk dalam berita Tribunnews.com ${ }^{1}$

Yang menarik, foto-foto ini tidak hanya beredar secara lepas di masyarakat. Beberapa pihak bahkan memanfaatkannya untuk tujuan politis. Beberapa partai politik menggunakan foto Soeharto ini dalam baliho-baliho kampanye mereka.

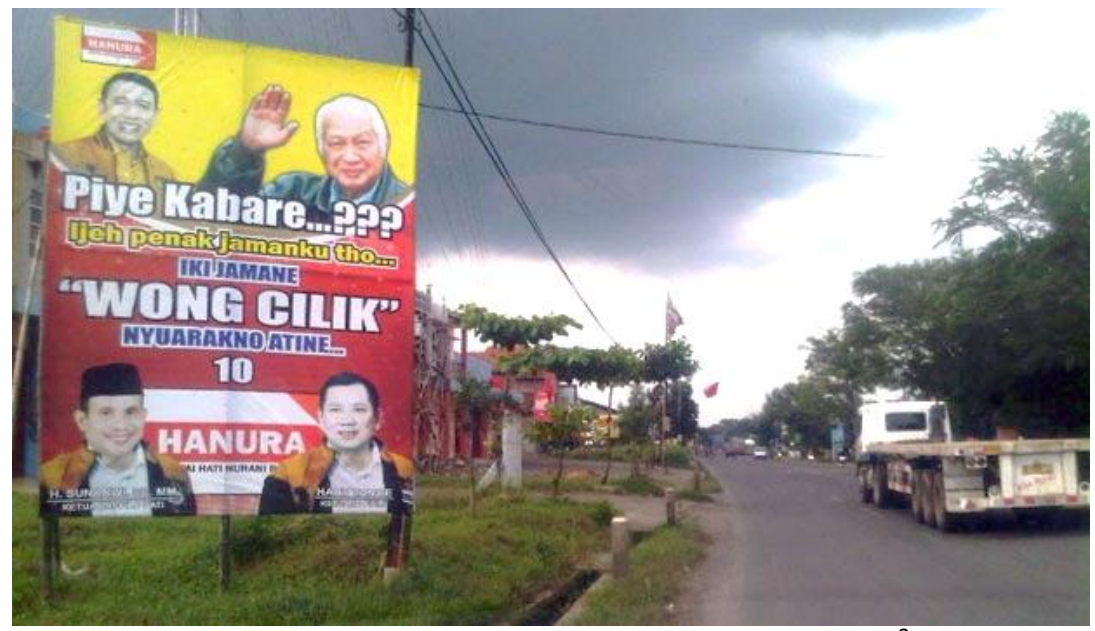

Gambar 2. Baliho Kampanye Partai Hanura²

${ }^{1}$ Adhy Kelana. Stiker Mantan Presiden Soeharto Nempel di Angkot 2013, dalam http://www.tribunnews.com/images/regional/view/669201/stiker-mantanpresiden-soeharto-nempel-di-angkot\#img diakses tanggal 17 Oktober 2014

${ }^{2}$ Roffiudin "Partai Hanura Cabang Pati, Jawa Tengah, memasang baliho bergambar foto Ketua Umum Partai Hanura Wiranto dan Harry Tanoe Soedibyo, berdampingan dengan foto bekas Presiden RI, Soeharto yang tersenyum sambil melampaikan tangan." dalam artike oleh Anang Zakaria. Seniman: Soeharto Piye Kabare Hasil Desain Serius, 2014, dalam 


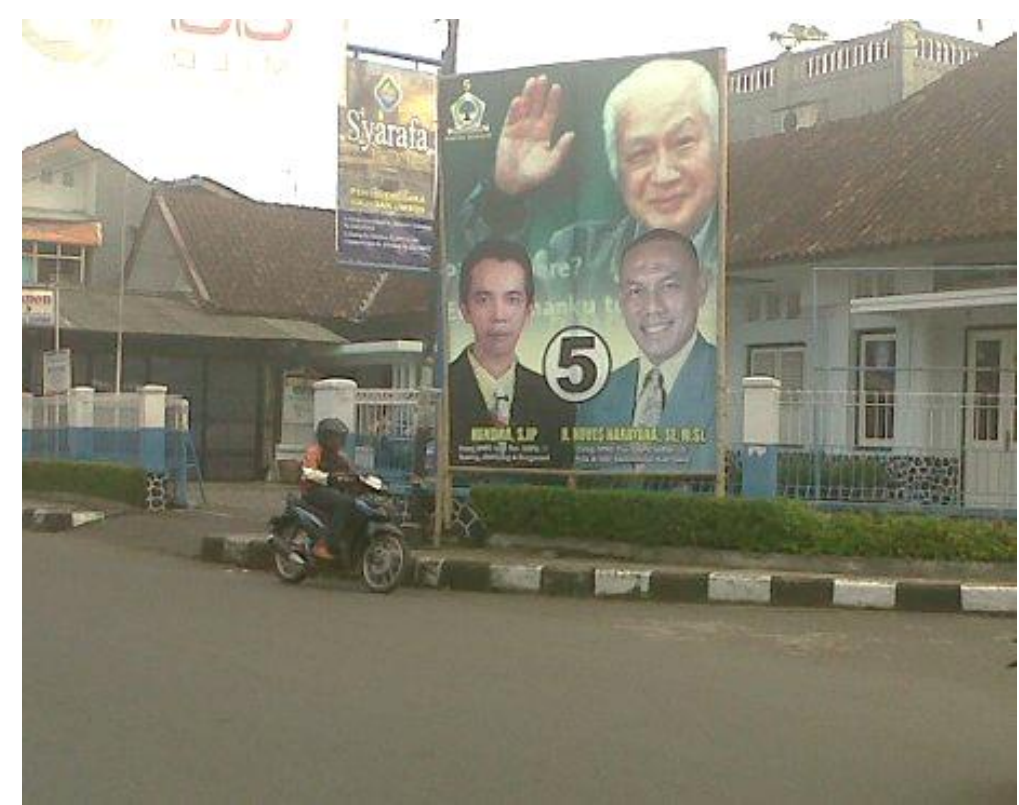

Gambar 3. Baliho Kampanye Calon Legislatif dari Partai Golkar ${ }^{3}$

Meski demikian, bukan berarti foto-foto ini sekedar sarana yang digulirkan oleh kalangan elit politik untuk kepentingan kampanye. Di kalangan masyarakat umum, khususnya di pulau Jawa, foto-foto ini cukup populer ditempelkan di angkutan umum, truk, becak beredar di situs-situ sosial media, dan bahkan dijual dalam bentuk kaos. Di bawah ini, penulis menyertakan foto gambar Soeharto di belakang sebuah truk. Di bawah gambar tersebut terdapat tulisan tangan sesorang yang menjawab pertanyaan Soeharto dengan semacam persetujuan dalam bahasa jawa "Ho'oh kayo ne" yang berarti “Iya, sepertinya".

http://www.tempo.co/read/news/2014/01/28/078548962/Seniman-SoehartoPiye-Kabare-Hasil-Desain-Serius diakses tanggal 17 Oktober 2014

${ }^{3}$ Kristiadi. Pasang Balibo Bergambar Soeharto Mesem, Ini alasan 'Tdeologis' Caleg Golkar, 2013, dalam

http://news.detik.com/read/2013/05/21/155421/2251992/10/pasang-balihobergambar-soeharto-mesem-ini-alasan-ideologis-caleg-golkar?nd771104bci diakses tanggal 17 Oktober 2014 


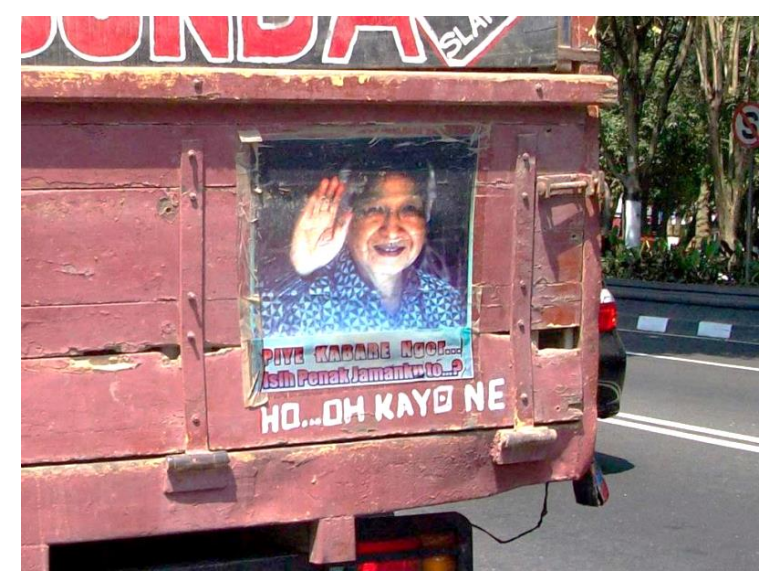

Gambar 4. Foto Soeharto di truk, ditanggapi dengan persetujuan ${ }^{4}$

Meski belum bisa ditemukan asal usul tersebarnya foto dan tulisan ini, namun bisa dilihat bahwa fenomena ini cukup ramai ditanggapi oleh masyarakat. Pada tanggal 25 November 2013, Andreas Nugroho, seorang wartawan BBC di Jakarta menulis berita tentang fenomena ini di situs bbc.co.uk. ${ }^{5}$ Secara khusus, Nugroho meliput ramainya penjualan kaos bergambar Soeharto dengan tulisan "piye kabar'e le? Penak jamanku to?" di daerah Malioboro, Yogyakarta. Menurut pengakuan para penjual, mereka menjual kaos ini bukan karena alasan politik, tetapi karena tingginya minat pembeli. Dalam sehari, kaos ini bisa terjual sampai 20 buah, menurut salah seorang penjual. ${ }^{6}$

Berbarengan dengan fenomena ini, pada tanggal 8 Juni 2013, didirikan juga Museum Memorial Jenderal Besar (Purn.) H. M. Soeharto di Kemusuk, Bantul, Yogyakarta oleh Probosutedjo, adik dari Alm. Soeharto. Nugroho datang dan mewawancara beberapa pengunjung museum. Ada yang datang membawa anak-anaknya, supaya mereka bisa membedakan zaman Soeharto dengan era reformasi, karena menurutnya zaman Soeharto lebih nyaman karena tidak banyak kerusuhan. ${ }^{7}$ Museum yang mengklaim sudah dikunjungi lebih dari 93.000 pengunjung dalam lima bulan pertama

\footnotetext{
${ }^{4}$ Nini.ng Piye Kabare,..? Isih penak jamanku to,..??, 2013, dalam http:// niningwell.blogspot.com/2013/05/piye-kabare-isih-penak-jamanku-to.html diakses tanggal 17 Oktober 2014

5 Andreas Nugroho. Mengapa 'merindukan' sosok Subarto?, 2013 dalam http://www.bbc.co.uk/indonesia/laporan_khusus/2013/11/131125_lapsus_suhar to_baju_dan_museum diakses tanggal 20 Oktober 2014

6 Andreas Nugroho. Mengapa 'merindukan'.

${ }^{7}$ Demikian hasil wawancara dengan Sri Murti asal Tempel, Kab. Sleman, Yogyakarta seperti dikutip oleh Andreas Nugroho. Mengapa 'merindukan'.
} 
pembukaannya ini, juga menjadi tujuan para pelajar yang sedang mempelajari sejarah Indonesia, untuk belajar tentang mantan presiden ke-2 Republik Indonesia. ${ }^{8}$

Di dalam museum ini akan ditemukan beberapa diorama yang menggambarkan jasa-jasa Soeharto seperti perannya pada peristiwa tiga puluh September, Operasi Trikora di Irian Jaya hingga keberhasilan di masa pembangunan lima tahunan.Namun anda tidak akan menemukan catatan kritis seputar Soeharto saat dia masih berkuasa. Bagaimana dia memperlakukan orang-orang yang dituduh sebagai antek komunis atau penjelasan seputar kasus penculikan sejumlah aktivis menjelang Soeharto lengser. Cerita seputar penghentian penyelidikan terkait sejumlah kasus yang dituduhkan kepada Soeharto juga tidak akan ditemui di tempat ini. ${ }^{9}$

Pendirian Museum ini diakui memiliki tujuan untuk mengembalikan citra diri Alm. Soeharto. Selain itu, Probosutejo juga mengaitkannya dengan tujuan yang lebih umum, sebagaimana dikutip oleh Nugroho, "Tapi memang tujuannya untuk mencapai tujuan yang sebenarnya yaitu supaya bisa membangun dan tidak diganggu terus nanti pembangunankan rusak. Seperti kita lihat sekarang demonstrasi dimana-mana jadi karena demontarsi tidak menentu pembangunan tidak jalan."10

Hal-hal di atas menunjukkan bahwa maraknya foto Soeharto yang beredar, bukan sekedar fenomena ringan. Fenomena ini dikaitkan dengan kondisi bangsa Indonesia yang sedang tidak stabil dan bahkan dimanfaatkan untuk kepentingan politik menjelang Pemilu Legislatif dan Pemilu Presiden pada tahun 2014. Meskipun sekarang ini popularitas dari foto Soeharto sudah tidak seramai di tahun 2013, penulis meyakini bahwa kehadiran foto tersebut telah menggelitik bangsa ini dan memunculkan berbagai dampak di bumi Indonesia. Setidak-tidaknya, foto ini mengajak masyarakat Indonesia berpikir ulang tentang era Reformasi dan juga Orde Baru yang telah kita tinggalkan di tahun 1998.

Sementara itu, penulis juga menemukan gejala serupa dalam kitab Keluaran. Setelah berhasil keluar dari perbudakan di Mesir, bangsa Israel beberapa kali menyuarakan keinginan untuk kembali ke Mesir, atau setidaknya lebih memilih mati di Mesir daripada berada di padang gurun.

\footnotetext{
${ }^{8}$ Andreas Nugroho. Mengapa 'merindukan.'

9 Ibid.

${ }^{10}$ Probosutejo dikutip oleh Andreas Nugroho. Mengapa 'merindukan.'
} 
${ }^{10}$ Ketika Firaun telah dekat, orang Israel menoleh, maka tampaklah orang Mesir bergerak menyusul mereka. Lalu sangat ketakutanlah orang Israel dan mereka berseru-seru kepada TUHAN, ${ }^{11}$ dan mereka berkata kepada Musa: "Apakah karena tidak ada kuburan di Mesir, maka engkau membawa kami untuk mati di padang gurun ini? Apakah yang kau perbuat ini terhadap kami dengan membawa kami keluar dari Mesir? ${ }^{12}$ Bukankah ini telah kami katakan kepadamu di Mesir: Janganlah mengganggu kami dan biarlah kami bekerja pada orang Mesir. Sebab lebih baik bagi kami untuk bekerja pada orang Mesir dari pada mati di padang gurun ini." (Kel 14:10-12, ITB)

${ }^{1}$ Setelah mereka berangkat dari Elim, tibalah segenap jemaah Israel di padang gurun Sin, yang terletak di antara Elim dan gunung Sinai, pada hari yang kelima belas bulan yang kedua, sejak mereka keluar dari tanah Mesir. ${ }^{2}$ Di padang gurun itu bersungut-sungutlah segenap jemaah Israel kepada Musa dan Harun; ${ }^{3}$ dan berkata kepada mereka: "Ah, kalau kami mati tadinya di tanah Mesir oleh tangan TUHAN ketika kami duduk menghadapi kuali berisi daging dan makan roti sampai kenyang! Sebab kamu membawa kami keluar ke padang gurun ini untuk membunuh seluruh jemaah ini dengan kelaparan." (Kel 16:13, ITB)

${ }^{3}$ Hauslah bangsa itu akan air di sana; bersungut-sungutlah bangsa itu kepada Musa dan berkata: "Mengapa pula engkau memimpin kami keluar dari Mesir, untuk membunuh kami, anak-anak kami dan ternak kami dengan kehausan?" (Kel 17:3, ITB)

Dalam teks-teks di atas, umat Israel secara explisit membandingkan kondisi krisis yang mereka alami di padang gurun dengan apa yang terjadi di Mesir. Dalam Kel 14:12, mereka bahkan secara terbuka menyatakan kesediaan mereka untuk bekerja kepada orang Mesir daripada harus menghadapi resiko kematian di padang gurun. Tiga kali bangsa Israel, menuduh bahwa Musa membawa mereka keluar dari Mesir untuk membunuh mereka di padang gurun.

Untuk kedua teks ini, penulis ingin melakukan penafsiran dengan metode dialog imajinatif dan pendekatan poskolonial. Seperti yang penulis tuliskan di atas, teks ini lahir dari dua bangsa yang sebelumnya menghadapi ketertindasan. Mereka sudah lepas dari kondisi tersebut, tetapi melalui teks-teks yang ada, bisa kita lihat bahwa Indonesia dan Israel belum benar-benar selesai dengan pengalaman 
mereka baik selama Orde Baru, maupun dengan perbudakan di Mesir. Melihat hal ini, penulis merasa pendekatan poskolonial bisa menolong penulis untuk menggali lebih dalam pergumulan yang melatarbelakangi kelahiran teks-teks yang ada.

Memang, jika kita kembali kepada pengertian kolonialisme, ${ }^{11}$ teks-teks ini sepertinya tidak memiliki keterkaitan langsung dengan apa yang menjadi pusat perhatian poskolonialisme. Meski demikian, perlu kita sadari bahwa diskursus poskolonial sudah berkembang ke titik dimana penggunaannya tidak lagi terbatas pada pembahasan tematema kolonialisme Eropa paska-pencerahan. Sugirtharajah mencatat perkembangan ini dalam bukunya Exploring Postcolonial Biblical Criticism.

Meanwhile, postcolonialism has embraced a wide variety of disciplinary field which have not usually been open to postcolonial inquiry. It has now expanded to include all forms of oppression and subjugation ranging from disability studies to queer studies... which at first glance might not have been seen as having any postcolonial interest. ${ }^{12}$

When it emerged, its perspectives were seen as "the colonial testimony of Third World countries and the discourses of 'minorities' within the geopolitical divisions of East and West, North and South", but now it is not confined exclusively to that group. Its approaches, positions, and traits are extended to any group who face discriminatory practices. ${ }^{13}$

Melalui pernyataan di atas, kita melihat bagaimana bidang ilmu yang tadinya berfokus pada relasi negara dunia ketiga dengan penjajahnya, yaitu negara-negara di Eropa, telah melebarkan sayapnya.

${ }^{11}$ Terma kolonialisme secara khusus digunakan untuk mendefinisikan bentuk spesifik dari eksploitasi kebudayaan yang dikembangkan bersamaan dengan ekpansi Eropa selama 400 tahun terakhir. Ekspansi kolonial Eropa paskapencerahan bersamaan dengan perkembangan sistem perekonomian kapitalis modern, sehingga pandangan bahwa koloni didirikan terutama untuk mensuplai bahan mentah bagi perkembangan ekonomi penjajah semakin dikuatkan dan diinstitusionalisasikan. Hal ini juga berarti bahwa relasi antara penjajah dan terjajah terkungkung dalam hierarki perbedaan yang kaku dan resisten terhadap pertukaran yang adil dan setara, baik di bidang ekonomi, budaya dan sosial. penjelasan lebih lanjut tentang kolonialisme, Iih. "Colonialism" dalam Bill Ashcroft, dkk. Key Concepts in Post-Colonial Studies (London and New York: Routledge, 1998) 45-51.

12 R. S. Sugirtharajah, Exploring Postcolonial Biblical Criticism: History, Method, Practice (Chichester: Wiley-Blackwell, 2012), 19.

${ }^{13}$ Ibid., 21. 
Sekarang ini, poskolonialisme bisa digunakan untuk menganalisa berbagai bentuk penindasan dan marginalisasi.

Alasan penulis memilih teks-teks di atas untuk didialogkan dengan fenomena foto Soeharto adalah karena penulis menemukan adanya kemiripan pola dari keduanya.

1. Kedua teks ini muncul dari dua bangsa yang sebelumnya mengalami ketertindasan.

2. Keduanya berbicara tentang masa sebelumnya yang sarat penindasan, namun dipandang dengan penuh kerinduan.

3. Kerinduan ini muncul ketika kedua bangsa menghadapi krisis. Berdasarkan kemiripan pola yang terlihat, penulis melihat celah untuk mempertemukan kedua fenomena ini, untuk menggali makna yang lebih mendalam. Menurut penulis, dengan metode dialog imajinatif, kedua fenomena ini bisa saling memperkaya. Sebagai seorang Kristen Indonesia, kita bisa memaknai dan menyikapi kondisi politik Indonesia dengan diperkaya oleh narasi iman Kristen. Sebaliknya, melalui pemahaman yang mendalam tentang situasi di sekitar kita, bisa dibangun sebuah konstruksi iman yang lebih kontekstual dan bertanggung jawab.

\section{Metode Tafsir: Dialog Imajinatif}

Pui-Lan menguraikan sebuah proses hermeneutik yang ia temukan dari cara para teolog Asia, termasuk dirinya sendiri, menafsirkan Alkitab. Proses hermeneutik ini ia sebut "dialog imajinatif ${ }^{14,}$. Melalui metode ini, seorang Asia yang hidup di lingkungan yang kaya dengan berbagai tradisi agama dan budaya mampu mendialogkan tradisinya sendiri dengan tradisi Alkitab yang sudah sangat dipengaruhi teologi barat. Sebagaimana Bevans, Kwok Pui-Lan juga setuju bahwa perubahan sosial atau, yang dalam tulisannya disebut biografi sosial, ${ }^{15}$ juga merupakan bagian dari tradisi yang dimaksudkan.

Melalui metode ini, Pui-Lan menggabungkan proses imajinasi dengan dialektika antara tradisi Alkitab dan konteks Asia. Pui-Lan mengutip tahapan dalam proses imajinasi dari Sharon Parks:

- A consciousness of conflict (something not fitting)

- Apause

\footnotetext{
${ }^{14}$ Kwok Pui-Lan, Discovering the Bible in the Non-Biblical World. (New York: Orbis Books, 1983), 12.

${ }^{15}$ Ibid., 13.
} 
- The finding of a new image

- The repatterning of reality and interpretation ${ }^{16}$

Di dalam metode dialog imajinatif ini, tahapan-tahapan proses imajinasi yang ada dilakukan sambil terus mempertemukan kedua tradisi dalam dialektika. Pui-Lan mengatakan bahwa sebagai seorang Asia, kita perlu melibatkan dialektika dalam proses imajinasi. Di satu sisi kita harus mengimajinasikan bagaimana tradisi Alkitab, yang dibentuk di waktu dan tempat yang berbeda, bisa menjawab permasalahan kita sekarang ini. Di sisi lain, kita harus mengimajinasikan ulang dunia Alkitab berdasarkan kondisi masa kini, sehingga bisa membuka cakrawala baru yang selama ini tersembunyi bagi kita. ${ }^{17}$

Menurut Pui-Lan, metode dialog imajinatif harus mengadopsi cara kerja multi-axial dalam melakukan analisa. Yang dimaksud dengan cara kerja multi-axial adalah metode yang mengintegrasikan dan mempertimbangkan isu-isu gender, ras, kelas dan perbedaan kultural dalam melakukan analisa. ${ }^{18}$ Lebih lanjut dalam buku yang sama, PuiLan mengusung pembacaan poskolonial sebagai perspektif multidimensional yang mempertemukan isu rasial, seksisme, dan imperialisme agama dan budaya dalam sejarah penafsiran teks. ${ }^{19}$ Penulis sependapat dengan penjelasan Pui-Lan, bahwa jika kita menggunakan metode dialog imajinatif dengan cara kerja multi-axial, kita perlu mengadopsi persepektif yang multi dimensional seperti poskolonialisme. Dalam bukunya yang kemudian, Pui-Lan melihat kembali usulannya tentang metode dialog imajinatif dan menambahkan bahwa orang Kristen di Asia tidak bisa mengabaikan kenyataan bahwa kebanyakan kebudayaan lokal Asia yang ingin didialogkan dengan iman Kristen sudah sangat dipengaruhi oleh kolonialisme, oleh karena itu poskolonialisme sebagai sebuah cara pandang juga diperlukan dalam melakukan dialog imajinatif. ${ }^{20}$

Pembacaan yang demikian ini, menekankan pluralitas makna dan kesadaran bahwa teks bukanlah sesuatu yang mengambang tanpa relasi dengan konteks di sekitarnya. Pembacaan dengan model dialogis memungkinkan kita bergumul dengan narasi-narasi yang berbeda

\footnotetext{
${ }^{16}$ Sharon Parks, The Critical Years: The Young Adult Search for a Faith to Live By (San Fransisco: Harper and Row, 1986) seperti dikutip oleh Pui-Lan. Discovering., h.13

17 Pui-Lan, Discovering the Bible, 13.

18 Ibid., 39.

${ }^{19}$ Ibid., 79.

${ }^{20}$ Kwok Pui-Lan, Postcolonial Imagination and Feminist Theology (Louisville: Westminster John Knox Press, 2005), 41.
} 
dalam waktu yang bersamaan, menelaah versi-versi yang berbeda dari setiap kisah, dan memunculkan narasi-narasi alternatif. ${ }^{21}$ Dalam hal ini, penulis akan menggunakan metode dialog imajinatif untuk mempertemukan dua teks yang berbicara mengenai tema-tema yang memiliki kemiripan, namun berangkat dari konteks kehidupan masingmasing komunitas yang menghidupinya.

Sementara itu, untuk mempermudah pembacaan kedua teks, penulis menggunakan metode tafisr narasi untuk membaca teks Keluaran dan metodi semiotika media untuk membaca foto Soeharto.

\section{Pendekatan Poskolonial: Poskolonialitas}

Sebagai sebuah bidang ilmu, poskolonialisme mencakup berbagai macam pandangan dan pendekatan yang berbeda tentang berbagai tema seperti damapak kolonialisme, relasi Barat-Timur, dan perjuangan kaum marginal. Oleh karena itu, penulis merasa perlu untuk memberi batasan dan memilih beberapa tema dari poskolonialisme yang sekiranya bisa membantu kita dalam proses dialog imajinatif. Penulis menitikberatkan uraian dalam bab ini pada pembahasan mengenai poskolonialitas atau kondisi yang dihadapi masyarakat paska penindasan.

\section{Amnesia Poskolonial}

Setelah mengalami penindasan dan akhirnya terbebas, manusia yang tertindas hidup di dalam masa peralihan antara ketertindasan dan kemerdekaan, antara masa lalu dan masa kini. Pada dasarnya manusia paska penindasan cenderung mengharapkan bahwa peralihan ini berbentuk transisi linear dan bersifat diskontinu, dimana ketertindasan diharapkan selesai begitu saja dan subjek pada saat itu juga mampu menjadi manusia merdeka seutuhnya. Leela Gandhi setuju dengan Albert Memmi, yang berpendapat bahwa negara paska-kolonial terperdaya oleh anggapan bahwa rancangan dunia baru akan muncul secara ajaib dari reruntuhan kolonialisme. Demikian Gandhi mengutip Memmi: "And the day oppression ceases, the new man is supposed to emerge before our eyes immediately." 22

${ }^{21}$ Pui-Lan, Discovering the Bible., 38.

${ }^{22}$ Albert Memmi, Dominated Man: Notes Toward a Portrait (London: Orion Press, 1968), 88 seperti dikutip oleh Leela Gandhi, Postcolonial Theory: A Critical Introduction (St. Leonards: Allen \& Unwin, 1998), 6. 
Keinginan untuk memulai awal baru membuat negara-negara ini hidup dalam ketergesaan untuk mewujudkannya dan takut gagal menjawab keinginan dan harapan akan kemerdekaan yang utuh. Seolah-olah jika tidak segera dilakukan pembersihan diri dari segala sesuatu yang berbau kolonial, maka kolonialisme akan kembali menguasai dan mempengaruhi kehidupan bangsa. Oleh karena itu, negara-negara merdeka paska kolonial memilih untuk merepresi dan melupakan pengalaman kolonial masa lalu. Leela Gandhi menyebut hal ini sebagai amnesia poskolonial yaitu, gejala adanya dorongan swapenciptaan sejarah atau kebutuhan untuk memulai awal baru, demi menghapus pelbagai kenangan menyakitkan tentang subordinasi kolonial. $^{23}$

Gandhi mengutip Lyotard yang mengatakan tentang amnesia poskolonial, "pemutusan (diskontinuitas antara masa kolonial dan setelah merdeka, red.) ini sebenarnya merupakan jalan untuk melupakan dan merepresi masa lalu, katakanlah, untuk mengulanginya dan tidak melampauinya." ${ }^{24}$ Dalam hal ini, penulis sependapat dengan Lyotard. Amnesia poskolonial bukan penyelesaian masalah bagi negara-negara paska kolonial. Represi masa lalu sangatlah berbeda dengan upaya melampauinya. Meminjam penjelasan dari psikoanalisa, represi adalah salah satu defense mechanism-strategi bawah sadar dari ego untuk mengaburkan realita dan mengurangi kecemasan ${ }^{25}$. Untuk melindungi diri dari pengalaman traumatis, kita menekan memori terkait pengalaman tersebut. Frantz Fanon, seorang psikoanalis dari Algeria menggunakan pengetahuannya tentang ilmu ini untuk menjelaskan relasi subordinasi kaum kulit hitam oleh pihak Barat. Dalam buku Black Skin, White Masks, Fanon menyajikan penjelasan Freud tentang proses represi ini.

This trauma, it is true, has been quite expelled from the consciousness and the memory of the patient and as a result he has apparently been saved from a great mass of suffering, but the repressed desire continues to exist in the unconscious; it is on watch constantly for an opportunity to make itself known and it soon comes back into consciousness, but in a disguise that makes it impossible to recognize; in other words, the repressed thought is replaced in consciousness by another that acts as its surrogate, its Ersatr, and that soon surrounds itself with all those

\footnotetext{
${ }^{23}$ Gandhi, Postcolonial Theory, 4.

24 Ibid., 7.

${ }^{25}$ Sharon Heller, Freud $A$ to $Z$ (New Jersey: John Wiley \& Sons., 2005), 67.
} 
feelings of morbidity that had been supposedly averted by the repression. $^{26}$

Jika kita mengikuti penjelasan Fanon, bisa kita lihat bahwa represi memori secara sekilas terlihat mampu menyelamatkan subjek dari penderitaan. Tapi pada kenyataannya, represi ini hanya mengalihkan trauma tersebut menjadi bentuk yang lain, yang justru lebih tersamar dan sulit dideteksi. Trauma ini masih membawa dan menghadirkan penderitaan yang sama, meskipun telah berganti wujud.

\section{Limbo Poskolonial}

Sebagaimana uraian di atas, bisa kita lihat bahwa upaya amnesia poskolonial tidaklah menyelesaikan masalah, namun hanya menekannya untuk kemudian akan muncul kembali dalam berbagai bentuk yang lain. Oleh karena itu, Leela Gandhi melihat bahwa upaya ini biasanya berujung kepada kegagalan dan kekecewaan. Peralihan dari masa penindasan kepada kemerdekaan penuh tidak terjadi dalam sekejap mata. Di dalam euforia, mereka telah bersusah payah menghapus segala sesuatu yang berbau kolonial dan membentuk identitas nasional yang baru, untuk kemudian menemukan bahwa negara yang mereka bangun masih jauh dari apa yang mereka impikan. Kondisi yang demikian ini menghadirkan perasaan disorientasi dan membuat kita seperti kehilangan arah. Di satu sisi mereka telah merdeka, namun di sisi lain mereka harus berhadapan dengan kenyataan bahwa status baru mereka tidaklah serta-merta membawa mereka lepas dari pengaruh kolonial. Masih mengutip Memmi, Leela Gandhi menjelaskan bahwa harapan ini tidak dimungkinkan karena adanya apa yang disebut the psychologically tenacious bold of the colonial past on the postcolonial present. ${ }^{27}$ Sekali lagi, negara paska kolonial akan menemukan dirinya masih membawa memori kolonial ke dalam kondisinya yang telah merdeka. Kondisi paska penindasan atau poskolonialitas adalah kondisi dimana masa lalu dan masa kini, penindasan dan kemerdekaan hadir secara bersamaan dan mempengaruhi kehidupan manusia dalam membentuk identitasnya.

Dengan bahasa yang sedikit berbeda, Leela Gandhi mengutip Albert Memmi yang memandang poskolonialitas sebagai sebuah kondisi historis yang ditandai dengan alat kebebasan yang terlihat dan

${ }^{26}$ Frantz Fanon, Black Skin, White Masks (London: Pluto Press, 2008), 111.

${ }^{27}$ Gandhi, Postcolonial Theory, 6. 
presistensi ketidakbebasan yang tersembunyi. ${ }^{28}$ Alat kebebasan mewakili kondisi masa kini yang sudah merdeka, sedangkan presistensi ketidakbebasan mewakili kondisi masa lalu yang terjajah dan pengaruh psikologisnya. Ketidakbebasan dikatakan presisten, karena ia tetap bertahan, ada dan mempengaruhi manusia poskolonial meskipun secara fisik dan hukum mereka telah merdeka. Baginya kondisi seperti ini merupakan sebuah penyakit limbo poskolonial. ${ }^{29}$

\section{Residu Kolonial}

Lebih lanjut, Gandhi menyetujui Memmi yang berpendapat bahwa limbo poskolonial ini diakibatkan oleh residu jejak dan memori akan penindasan. ${ }^{30}$ Senada dengan Jenny Sharpe yang penulis kutip di awal Bab ini, Homi K. Bhabha menyebut residu kolonial ini sebagai 'masa lalu yang terbungkam, yang menghantui masa kini.'

Menarik untuk diperhatikan bahwa Bhabha menggunakan istilah 'masa lalu yang terbungkam.' Berbicara tentang perbudakan orang kulit hitam, Sharpe menganalogikan represi dan pembungkaman masa lalu dengan proses pemakaman jenazah dengan cara yang tidak layak sehingga sama seperti roh jenazah tersebut yang menjadi hantu gentayangan, maka masa lalu juga akan terus menghantui masa kini. ${ }^{32}$ Keterbungkaman narasi penindasan menjadi penyebab adanya residu kolonial, atau dalam bahasa Sharpe dan Bhabha, hantu masa lalu. Pendapat kedua tokoh ini senada dengan pemikiran Leela Gandhi yang telah kita bahas di atas mengenai amnesia poskolonial. Amnesia poskolonial mengantarkan kita kepada kondisi limbo, karena upaya represi yang dilakukan justru membentuk residu-residu kolonial yang terus mempengaruhi masyarakat paska kolonial.

Selain pengaruh psikologis dari kolonialisme yang disebutkan di atas, residu kolonial ini termasuk juga aspek struktural seperti kerusakan landasan ekonomi, budaya dan politik yang diakibatkan oleh kolonialisme. Penulis memandang hal di atas sangat penting untuk

${ }^{28}$ Ibid., 6-7.

${ }^{29}$ Limbo (n.) 2. An intermediate state or condition of awaiting a decision etc. 4. A state of neglect or oblivion. Berdasarkan "Limbo." Judy Pearsall dan Bill Trumble, The Oxford English Reference Dictionary: Second Edition (Oxford: Oxford University Press, 1996) 832.

${ }^{30}$ Gandhi. Postcolonial Theory, 7.

${ }^{31}$ Homi K. Bhabha, The Location of Culture, (London dan New York: Routlegde, 1994), 12.

${ }^{32}$ Jenny Sharpe, ed. Ghost of Slavery: A Literary Archeology of Black Women's Lives (Minneapolis: University of Minnesota Press, 2003), xi. 
disadari. Kolonialisme meninggalkan bekas luka yang sangat dalam baik secara struktural maupun psikologis dan kedua hal ini memiliki kaitan erat, seperti yang akan bisa kita lihat dalam pembahasan selanjutnya.

Salah satu residu yang akan kita bahas dalam bab ini adalah perasaan inferior yang dimiliki masyarakat paska penindasan. Penulis memilih membahas ini, karena memandang bahwa pembahasan ini akan menolong kita untuk melihat konteks foto Soeharto dan narasi Keluaran dengan lebih jelas. Sebagai masyarakat paska penindasan, penulis memandang bahwa bangsa Indonesia maupun Israel masih memiliki perasaan inferior. Fanon membahas tentang perasaan inferior ini dengan lebih mendalam dan mencoba menelihat kembali mitos bahwa inferioritas kulit hitam adalah sebuah fakta apriori yang sudah ada bahkan sebelum kedatangan kulit putih. Baginya, inferioritas kaum kulit hitam justru sangat terkait dengan perasaan superior kaum kulit putih. $^{33}$

Melalui pengamatannya, Fanon menemukan gambaran umum bahwa orang kulit putih yang bertemu dengan seorang kulit hitam bersikap tepat seperti orang dewasa yang sedang mengahadapi anak kecil. ${ }^{34}$ Sikap ini bisa ditelusur sampai pada pemahaman Kant tentang pencerahan. Leela Gandhi mengutip penjelasan Kant yang menganggap bahwa pencerahan membukakan jalan bagi manusia untuk keluar dari sikap kekanak-kanakan kepada keadaan yang semakin dewasa. ${ }^{35}$ Selain itu, Gandhi juga mengutip Leonardo Bruni, seorang humanis masa pencerahan di Italia, yang menempatkan humanisme sebagai bidang ilmu yang menawarkan pendidikan yang lengkap bagi manusia: "the litterae are about to return with all their fertility, to form whole men, not just scholars. They call themselves studia humanitatis because they shape the perfect man." ${ }^{, 36}$ Pandangan-pandangan seperti inilah yang membentuk hierarki antara Eropa yang telah mengalami pencerahan dan koloni mereka yang masih hidup di dalam kegelapan. Kolonialisme mendapatkan legitimasi dari pemisahan yang kaku antara dewasa/kekanak-kanakan, beradab/barbar, maju/berkembang, dan progresif/primitif. ${ }^{37}$ Pemisahan ini menempatkan mereka sebagai pihak superior dan yang lain sebagai yang inferior dan membutuhkan "penyelamatan" melalui pencerahan agar menjadi "lebih manusia". Orang kulit putih datang ke Afrika dan benua lain dengan pandangan

\footnotetext{
${ }^{33}$ Fanon, Black Skin, 69.

${ }^{34}$ Ibid., 19.

${ }^{35}$ Gandhi, Postcolonial Theory, 30.

${ }^{36}$ Ibid., 46.

${ }^{37}$ Ibid., 32.
} 
bahwa sebagai manusia yang sudah tercerahkan, mereka lebih dewasa dan lebih sempurna dari bangsa-bangsa lain.

Kedatangan orang Eropa dengan perasaan superiornya, telah membawa orang kulit hitam kepada kondisi, dimana keberadaannya sebagai seorang manusia dipertanyakan.

If he is a Malagasy, it is because the white man has come, and if at the certain stage he has been led to ask himself wheter he is indeed a man, it is because his reality as a man has been challenged. In other words, I begin to suffer from not being a white man to the degree that the white man imposes discrimination on me, makes me a colonized native, robs me of all worth, all individuality, tells me that I am a parasite on the world, that I must bring myself as quickly as possible into step with the white world... Then I will simply try to make myself white: that is, I will compel the white man to acknowledge that I am human. ${ }^{38}$

Mereka yang berkulit hitam, hidup dalam kesadaran bahwa dirinya hina, rendah dan bukan manusia sehingga mereka tidak mempunyai pilihan lain. Untuk menjadi lebih manusia, ia harus menjadi "putih" dan hidup untuk menyenangkan "orang kulit putih". Jika tidak demikian, maka ia akan selamanya hidup sebagai "kulit hitam" dalam perasaan inferior dan bahkan bukan sebagai manusia.

In other words, the Malagasy can bear not being a white man; what hurts him cruelly is to have discovered first (by identification) that he is a man and later that men are divided into whites and blacks. If the "abandoned" or "betrayed" Malagasy continues his identification, he becomes clamorous; he begins to demand equality in a way he never before found necessary. The equality he seeks would have been beneficial before he started asking for it, but afterwards it proves inadequate to remedy his ills -for every increase in equality makes the remaining differences seem the more intolerable, for they suddenly appear agonizingly irremovable. This is the road along which (the Malagasy) passes from psychological dependence to psychological inferiority. ${ }^{39}$

\footnotetext{
${ }^{38}$ Fanon, Black Skin, 73.

${ }^{39}$ O. Mannoni. Prospero and Caliban: The Psychology of Colonialization (New York: Praeger, 1964), 40; seperti dikutip oleh Fanon, Black Skin, 72-73.
} 
Demikian Fanon mengutip O. Mannoni, seorang psikoanalis Prancis yang menulis tentang fenomena psikologi dalam relasi antara penjajah dan yang terjajah. Jika kita mengikuti pemikiran Mannoni, maka dalam situasi seperti ini, tidak ada ruang ketiga bagi orang Madagaskar. Mereka harus memilih antara kebergantungan atau selamanya hidup dalam inferioritas. Orang kulit hitam yang mengalami pencerahan dan menyadari bahwa ia adalah manusia dan menuntut kemanusiaannya sebagai kulit hitam merupakan ketidakwajaran yang ditekan ke dalam kesadaran bahwa ia tetaplah inferior dari kulit putih. Fanon mengutip pandangan Mannoni yang mengikuti alur pikir pencerahan Eropa, mengenai hal ini.

When he [the Malagasy] has succeeded in forming such relations [of dependence] with his superiors, his inferiority no longer troubles him: everything is all right. When he fails to establish them, when his feeling of insecurity is not assuaged in this way, he suffers a crisis. ${ }^{40}$

If, however, he forgets his place, if he takes it into his head to be equal of the European, then the said European is indignant and casts out the upstart -who, in such circumstance, in this "exceptional case," pays for his own rejection of dependence with an inferiority complex. ${ }^{41}$

Penulis tidak setuju dengan pandangan O. Mannoni. Di dalam uraiannya mengenai kondisi psikologis orang kulit hitam, Mannoni menganggap orang kulit hitam yang memperjuangkan kesetaraan, sebagai orang yang lupa akan posisinya. Dalam kutipan sebelumnya, Manonni bahkan mengatakan bahwa kondisi inequality antara kulit hitam dan kulit putih adalah penyakit yang tidak mungkin disembuhkan (Mannoni merujuk perbedaan orang kulit hitam dari kulit putih sebagai "ills"). Menurut penulis, pandangan beliau muncul dari anggapan bahwa inferioritas kulit hitam adalah fakta apriori dan merupakan sesuatu yang intrinsik telah ada dalam diri orang kulit hitam. Fanon mengutip pernyataan Mannoni mengenai hal ini : "The fact that when adult Malagasy is isolated in a different environment he can become suspectible to the classical type of inferiority complex proves almost beyond doubt that the germ of the complex was latent in him from childhood."42 Bagi Mannoni, inferioritas kulit hitam merupakan

\footnotetext{
${ }^{40}$ Fanon, Black Skin, 69

41 Ibid.

42 Ibid., 62.
} 
'penyakit bawaan' dan orang kulit hitam pada dasarnya memiliki posisi yang lebih rendah dari kulit putih.

Dalam hal ini, penulis setuju dengan pandangan Fanon bahwa inferioritas kulit hitam bukanlah 'penyakit bawaan', melainkan sangat terkait dengan perasaan superior dari orang kulit puitih. Inferioritas merupakan dampak dari kolonialisme. Sebuah drama berlangsung setiap hari di negara kolonial untuk memungkinkan hal tersebut terjadi. Fanon memberi contoh tentang seorang negro yang telah berhasil menyelesaikan kuliahnya dan pergi ke Sorbonne untuk melanjutkan studinya datang dengan perasaan was-was bahkan sebelum ia mengalami konflik apapun dengan orang kulit putih. Baginya gejala ini mampu dijelaskan melalui uraian Rene Menil.

It was "the consequence of the replacement of the repressed [African] spirit in the consciousness of the slave by an authority symbol representing the Master, a symbol implanted in the subsoil of the collective group and charged with maintaining order in it as a garisson controls a conquered city.",43

Leela Gandhi meminjam istilah Edward Said yang menyebut perasaan inferior ini sebagai "dreadful secondariness." 44 Senada dengan Fanon, menurutnya hierarki pengetahuan dan nilai-nilai kolonial yang masih tetap hidup dalam masyarakat paska kolonial, merupakan salah satu penyebab bertahannya kondisi keterjajahan dan terus memperkuat perasaan dreadful secondariness dari beberapa bangsa dan kebudayaan bahkan sampai saat ini. Di sini, kita kembali kepada catatan penulis di atas, tentang keterkaitan residu struktural dan psikologis dalam masyarakat paska kolonial. Kolonialisme membangun struktur yang secara berulang membentuk identitas yang terjajah sebagai inferior dan pada saat yang sama, memperkuat dan melegitimasi keberadaan penguasa sebagai yang superior. Di sisi lain, dan hal ini sepertinya kurang diperhatikan oleh Leela Gandhi dalam uraiannya, perasaan inferior ini memperkuat kebergantungan yang terjajah kepada penguasanya, sehingga pada saat yang bersamaan melegitimasi keberadaan struktur yang menindas tersebut. Hal inilah yang menyebabkan seorang kulit hitam tidak memiliki pilihan lain selain menjadi bergantung kepada kaum kulit putih atau hidup dengan perasaan inferior sebagai seorang kulit hitam. Konstruksi sosial Afrika Selatan dengan politik apartheid adalah contoh konstruksi yang rasis. Karena terbentuk di dalam sebuah struktur sosial dan menjadi bagian

\footnotetext{
${ }^{43}$ Ibid., 112.

${ }^{44}$ Gandhi, Postcolonial Theory., 7.
} 
dari kesadaran kolektif, maka inferiority complex atau dependency complex tidak bisa sekedar diselesaikan dalam skala individu dengan pendekatan psikoanalisis. Karena yang menyebabkan hal ini adalah struktur yang menindas maka penyelesaiannya juga harus menyentuh ke ranah sturukturnya.

In other words, the man should no longer be confronted by the dilemma, turn white or disappear. But he should be able to take cognizance of a possibility of existence. In still other words, if society makes difficulties for him because of his color, if in his dreams I establish the expression of an unconscious desire to change color, my objective will not be that of dissuading him from it by advising him to "keep his place"; on the contrary, consciousness, will be to put him in a position to choose action (or passivity) with respect to the real source of the conflict -that is, toward the social structures. ${ }^{45}$

Sekali lagi kita menemukan kaitan erat antara kondisi psikologis dan masalah struktural. Sebagaimana penulis mengungkapkan di atas bahwa inferioritas berperan melanggengkan struktur kolonial yang menindas, Fanon juga menyadari bahwa penyadaran di level individu akan memberi mereka kemampuan untuk bertindak di level struktural. Meski tidak secara langsung, namun orang kulit hitam yang mampu melampaui inferioritasnya, mau tidak mau akan ditempatkan pada posisi, dimana ia harus mengambil sikap (aktif atau pasif) terhadap struktur sosial yang selama ini membuatnya merasa inferior.

Hal ini berlaku juga dalam kasus penindasan yang lain. Fanon menekankan bahwa tidak ada yang berbeda dari rasisme di Amerika Utara, di koloni Prancis maupun anti-semitisme di era Nazi. Setiap bentuk inferioritas berkorelasi dengan klaim-klaim superior golongan yang lain.

All forms of exploitation are identical because all of them are applied against the same "object": man. When one tries to examine the structure of this or that form of exploitation from an abstract point of view, one simply turn one's back on the major, basic problem, which is that of restoring man to his proper place. $^{46}$

\footnotetext{
${ }^{45}$ Fanon, Black Skin, 75.

${ }^{46}$ Ibid., 65.
} 
Berangkat dari pemikiran Fanon, penulis memandang bahwa sampai batasan tertentu, poskolonialitas yang telah kita pelajari bersama bisa digunakan untuk membaca situasi psikologis dan sturktural masyarakat paska penindasan yang lain. Meski demikian, penulis tidak sedang berusaha memutlakkan cara pandang ini sebagai satu-satunya cara pandang yang paling tepat untuk menganalisa masyarakat paska penindasan.

\section{Dialog Imajinatif: Teks Keluaran dan Foto Soeharto}

Seperti yang sudah penulis uraikan dalam bagian latar belakang masalah, kedua teks ini penulis pilih karena beberapa alasan. Salah satu alasan tersebut adalah kedua teks ini berbicara tentang masa lalu yang sarat penindasan, namun dilihat dengan penuh kerinduan. Dalam kondisi normal, tidak seharusnya orang yang lepas dari penindasan menginginkan kembali kepada kondisi tersebut, atau sekurangkurangnya menganggap kondisi tersebut lebih baik daripada keadaan setelah bebas. Menurut penulis, hal ini pada dirinya sendiri menunjukkan adanya ketidaksesuaian, yang merupakan titik berangkat proses dialog imajinatif. Agar bisa melanjutkan proses dialog dengan lebih baik, penulis akan melakukan analisa lebih mendalam tentang munculnya kerinduan terhadap kondisi ketertindasan. Proses dialog ini tidak hanya melibatkan kedua teks, tetapi juga keseluruhan konteks dari mana teks ini lahir. Oleh karena itu, dalam pembahasannya penulis akan menarik berbagai informasi dari teks-teks lain yang ada di sekitar teks utama kita.

\section{A Consciousness of Conflict}

Untuk menganalisa ketidaksesuaian ini dengan lebih jelas, penulis hendak menggunakan sudut pandang poskolonial. Dalam bukunya, Leela Gandhi mengutip Albert Memmi yang melihat kondisi poskolonial sebagai sebuah kondisi historis yang ditandai oleh alat kebebasan yang terlihat dan presistensi ketidakbebasan yang tersembunyi. Secara kasat mata kita bisa melihat adanya keadaan baru, yaitu kondisi merdeka. Hal ini bisa terlihat melalui momentummomentum tertentu, seperti proklamasi kemerdekaan RI, 17 Agustus 1945 misalnya. Namun di balik itu, harus diakui bahwa kita belum benar-benar merdeka dari pengaruh negara-negara Barat. Bagi Memmi, kondisi ini adalah sebuah penyakit yang disebut limbo poskolonial, 
dimana ada tarik-menarik antara kedatangan dan kepergian, serta kemerdekaan dan ketertindasan. ${ }^{47}$

Kondisi seperti inilah yang menurut penulis sedang berlangsung dalam teks-teks yang menjadi fokus pembacaan kita. Dalam foto Soeharto, kita bisa menemukan sebuah tawar-menawar antara era reformasi yang (idealnya) tidak lagi militeristis dan bebas KKN (Korupsi Kolusi Nepotisme) dan Orde Baru yang lebih bersifat opresif. Sementara itu, dalam teks-teks kitab Keluaran kita bisa menemukan seruan langsung dari bangsa Israel yang di titik itu, lebih memilih untuk kembali ke perbudakan di Mesir daripada melanjutkan perjalanan di padang gurun sebagai bangsa merdeka. Perlu diperhatikan bahwa seruan untuk kembali ini tidak terjadi terusmenerus, baik di antara masyarakat Indonesia maupun Israel. Reformasi dan peristiwa keluaran bukanlah sesuatu yang sama sekali tidak diinginkan. Kedua bangsa ini juga ingin lepas dari ketertindasan, namun di saat-saat tertentu muncul keinginan untuk kembali.

Di bagian ini, kita akan mencoba melihat teks-teks yang menjadi subjek pembacaan kita dengan kesadaran baru tentang kondisi limbo poskolonial yang dihadapi bangsa Indonesia dan Israel, sambil terus memperhatikan latar belakang konteks masing-masing bangsa. Teks pertama yang berisikan keluhan bangsa Israel terdapat dalam Kel 14:10-12.

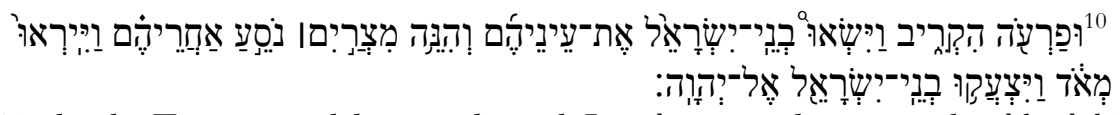

10. ketika Firaun mendekat, anak-anak Israel mengangkat mata, dan lihatlah! Orang-orang Mesir mengejar mereka dari belakang, maka sangat takutlah mereka dan berteriaklah anak-anak Israel kepada TUHAN.

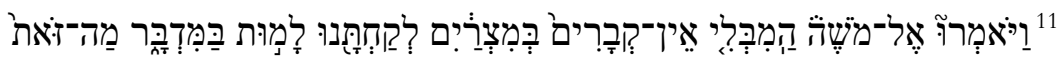

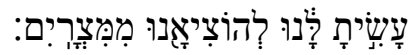

11. dan mereka berkata kepada Musa: "Apakah karena tidak ada kuburan di Mesir, engkau membawa kami di padang gurun ini? Mengapa engkau melakukan ini kepada kami dengan membawa kami keluar dari Mesir?

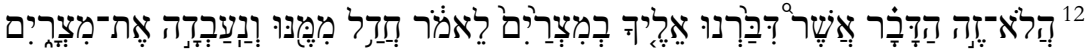

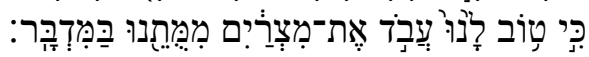

12. bukankan tentang hal ini, telah berkali-kali kami katakan kepadamu di Mesir: Pergilah dari kami dan biarkanlah kami bekerja untuk orang Mesir, sebab adalah keuntungan bagi kami untuk bekerja untuk orang Mesir daripada mati di padang gurun ini.

${ }^{47}$ Gandhi, Postcolonial Theory, 7. 
Hal ini terjadi segera sesudah mereka keluar dari Mesir, ketika mereka sedang berada di tepi laut Teberau. Di perhentian mereka yang pertama, mereka dikejar oleh Firaun dan pasukannya. Secara simbolik, kita bisa melihatnya sebagai sebuah pertemuan antara kebebasan dan presistensi ketidakbebasan. Di satu pihak bangsa Israel sudah menjadi bangsa merdeka dan bisa bepergian ke mana saja mereka mau, namun di belakang mereka masih ada bayang-bayang pengejaran Firaun, tuan mereka yang lama.

Begitu menyadari pengejaran Firaun, bangsa Israel menjadi sangat ketakutan dan mulai berteriak kepada TUHAN. Dalam edisi terjemahan baru, LAI (Lembaga Alkitab Indonesia) menerjemahkan $\mathrm{q}[\mathrm{c}$ dengan "berseru-beru", namun penulis memilih untuk menerjemahkannya dengan kata "berteriak" untuk menekankan kesan krisis yang saat itu sedang dihadapi bangsa Israel. Di titik itu, ketika mereka melihat kereta kuda Firaun, yang ada dalam pikiran bangsa Israel hanyalah kematian. Tidak ada masa depan bagi mereka yang sedang berhadapan dengan murka tuan mereka.

Pada saat itu jumlah orang Israel adalah 600.000 laki-laki sedang lawan mereka adalah 600 kereta berkuda Mesir. Meskipun memiliki kekuatan persenjataan, setiap kereta kuda Firaun harus melawan 1000 orang Israel. Satu melawan seribu bukanlah jumlah yang mudah untuk dikalahkan. Bisa dikatakan, bangsa Israel memiliki peluang yang sangat besar untuk menang. Disamping itu, Firaun sendiri sudah mengusir mereka, yang berarti sudah melepaskan ikatan mereka sebagai budaknya. Sebenarnya, Firaun sudah tidak memiliki hak apapun atas bangsa Israel dan penyerangan tersebut tidak dapat dibenarkan. Namun demikian, mereka bahkan tidak berpikiran untuk bangkit dan melawan. Lebih tepatnya, Israel tidak mampu berpikir bahwa mereka mampu melawan Mesir. Bagi mereka, Mesir adalah negara yang terlalu kuat untuk mereka lawan. Kereta kuda merupakan simbol kekuatan militer sebuah bangsa pada masa itu. Penggunaan kereta kuda untuk mengejar bangsa Israel merupakan deklarasi Firaun tentang kekuatan militernya dan superioritasnya atas bangsa Israel. Kehadiran kereta kuda bukan sekedar sebagai kendaraan, melainkan sebagai sebuah simbol kekuasaan Mesir yang mampu melumpuhkan bangsa Israel yang bertahun-tahun hidup di bawahnya.

Beralih ke Indonesia, presistensi ketidakbebasan mengambil wujud dalam maraknya foto Soeharto yang beredar di media elektronik maupun media cetak sekitar tahun 2013. Foto ini mulai beredar di awal tahun 2013, dan menjadi semakin populer sesudah kenaikan harga BBM Premium dari Rp 4.500,00 menjadi Rp 6.500,00 pada tanggal 22 Juni 2013. Kenaikan harga BBM ini menambah keresahan dan 
ketidakpuasan masyarakat kepada pemerintah. Belum lagi, kondisi politik saat itu mulai bergejolak dalam rangka menyambut pemilu Legislatif dan Presiden di tahun 2014. Masyarakat Indonesia mulai menganggap bahwa era Reformasi gagal menjawab tantangannya, untuk memperbaiki keadaan setelah Indonesia dilanda krisis pada tahun 1997. Kondisi bangsa Indonesia dianggap semakin parah.

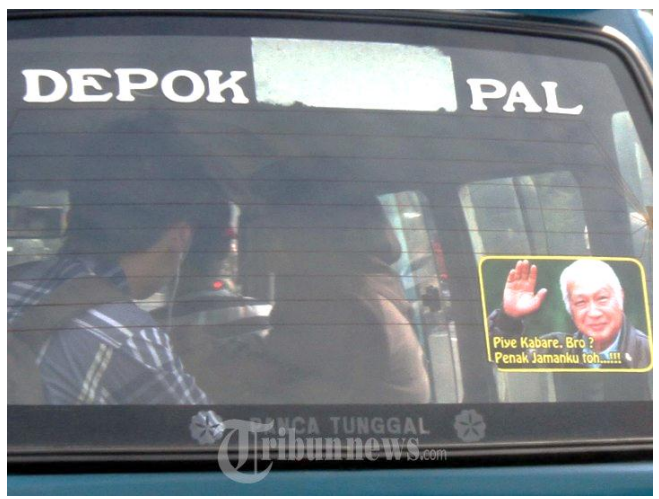

Gambar 5. Sticker Foto Soeharto di kendaraan umum masuk dalam berita Tribunnews.com ${ }^{48}$

Kekecewaan ini berakar pada ketergesaan bangsa Indonesia untuk melepaskan diri dari segala pengaruh Orde Baru dan harapan bahwa era Reformasi akan dengan segera mengubah manusia-manusia Indonesia menjadi manusia yang bebas dari $\mathrm{KKN}$ dan krisis multidimensi. Menariknya, foto yang beredar ini justru menyuarakan ajakan untuk mempertimbangkan ulang Orde Baru yang ditinggalkan. Meminjam analisa semiotika media, foto piye kabar'e sepertinya sedang berusaha menegosiasikan kembali interaksi antara masyarakat Indonesia dengan masa orde baru dan gaya kepemimpinan Soeharto yang militeristik.

Foto ini sepertinya menggunakan bentuk metonimi, ${ }^{49}$ dimana sosok Soeharto dengan senyumnya yang khas mewakili keseluruhan era orde baru dan gaya pemerintahan masa itu. Soeharto yang menjadi presiden tunggal selama era Orde Baru telah menjadi tanda yang mampu mewakili keseluruhan era tersebut. Dengan melihat foto Soeharto dan perkataan "jamanku", kita bisa langsung mengasosiasikan bahwa foto ini merujuk kepada Orde Baru. Secara

${ }^{48}$ Adhy Kelana, Stiker Mantan Presiden.

${ }^{49}$ Metonimi adalah asosiasi pelbagai peristilahan. Satu tanda diasosiasikan dengan tanda lain yang ditandakannya sebagian, keseluruhan, salah satu fungsi atau atributnya, atau konsep yang berkaitan dengannya. Lih. Tony Thwaites, dkk. Introducing Cultural and Media Studies: Sebuah Pendekatan Semiotik. (Yogyakarta: Jalasutra, 2009), 74. 
umum, pada masa Reformasi sekarang ini Orde Baru diasosiasikan dengan masa represi dan kebungkaman ketika dunia politik Indonesia dikontrol sedemikian rupa oleh Soeharto. Tidak ada demokrasi yang nyata saat itu. Tidak ada kebebasan bersuara. Orde Baru juga diasosiasikan dengan KKN dan berbagai macam krisis.

Meski demikian, foto Soeharto "piye kabar'e?" mengajak masyarakat Indonesia sebagai yang dialamatkan untuk mempertimbangkan kembali mitos ini. Foto Soeharto merupakan sebuah bacaan yang dinegosiasikan, dimana pembaca tidak secara total menempati peran si alamat, dan mempertanyakan sebagian mitosnya ${ }^{50}$. "Apakah benar seperti itu? Meski Orde Baru memiliki keburukannya, bukankah kebebasan di era reformasi tidak membawa kepada kesejahteraan? Bukankah kondisi Indonesia lebih stabil pada masa Orde Baru dibandingkan masa Reformasi? Bukankah sedikit tekanan lebih baik daripada kebebasan yang tidak terkontrol saat ini?" Pertanyaan terakhir ini menjadi salah satu poin penting pembacaan kita. Pada akhirnya, foto ini hendak menegosiasikan ulang kebebasan bangsa Indonesia yang disertai dengan krisis multidimensi pada masa reformasi dengan kepemimpinan militeristik a la Soeharto yang terbatas namun menjanjikan kestabilan. Pada saat foto ini sedang marak beredar, penulis sering mendengar berbagai opini tentang masyarakat Indonesia yang masih bermental 'terjajah' dan 'bodoh'. Opini ini kemudian diikuti dengan pendapat bahwa Indonesia membutuhkan pemimpin yang tegas, yang mampu mengontrol kekacauan di Indonesia. Hal ini kemudian membawa masyarakat untuk kembali merujuk kepada gaya kepemimpinan militeristik Soeharto yang dianggap akan mampu mengembalikan kestabilan di Indonesia.

Pertanyaan yang diajukan dalam foto tersebut "piye kabare Bro? Penak jamanku tob!!!” tidak bisa dilepaskan dari konteks pembaca saat itu. Seperti yang telah penulis gambarkan di atas, pada tahun 2013, Indonesia sedang berada di titik kritis perjalanannya. Menjelang pemilu legislatif dan presiden 2014, masyarakat mulai gelisah ketika diperhadapkan dengan berbagai permainan politik dan melihat krisis multi dimensi yang tak kunjung selesai. Masyarakat mulai mempertanyakan kredibilitas pemerintah era Reformasi dan kemampuannya untuk membawa bangsa ini keluar dari kondisi krisis. Bisa dikatakan bahwa pada saat itu, Indonesia sedang ada dalam kondisi limbo. Dalam kondisi demikian, foto ini hadir dan mengajak pembacanya untuk menengok kembali ke masa lalu.

Di sinilah, kita bisa melihat dengan jelas gejala penyakit limbo poskolonial di dalam kondisi Indonesia dan bangsa Israel. Fenomena

${ }^{50}$ Ibid., 133. 
foto Soeharto dan keluhan bangsa Israel bisa dilihat sebagai bukti adanya presistensi ketidakbebasan yang selama ini tidak tampak. Meski tidak ingin diakui, Indonesia masih menyimpan memori kebergantungan kepada rezim militer Orde Baru dalam mempertahankan kestabilan negara. Di sisi lain, bangsa Israel juga masih menyimpan kebergantungan seorang budak terhadap tuan mereka yaitu Mesir, dalam bentuk ketersediaan kebutuhan pokok seperti makanan dan minuman. Meskipun telah mendapatkan kebebasannya, kedua bangsa tidaklah serta-merta mampu melepaskan diri dari kebergantungannya kepada sang penguasa sebelumnya.

Dari pembahasan di atas, bisa kita katakan bahwa dua teks yang sedang kita dialogkan bukan sekedar fenomena sederhana yang bisa tenggelam seiring berjalannya waktu. Kedua teks ini mengakar pada sebuah kondisi psikologis ketidakbebasan yang presisten. Presisten di sini berarti, ia terus bertahan dan berusaha untuk tetap ada dan tidak bisa dengan mudah dilhilangkan.

Meski demikian, perlu dicatat bahwa kedua teks yang penulis pilih memiliki cara yang berbeda dalam penyampaiannya. Dalam foto Soeharto, suara ini berasal dari seorang pemimpin, yaitu mantan Presiden Soeharto. Melalui perkataannya, 'Piye kabar'e, penak jamanku to?" pembaca diminta membandingkan kondisi saat ini dan era Orde Baru. Dengan bahasa yang persuasif, pembaca diarahkan untuk mengakui bahwa kondisi Orde Baru lebih baik dari era reformasi. Sedangkan di dalam teks Keluaran, pernyataan memilih kondisi diperbudak di Mesir ditempatkan langsung di mulut orang Israel. Perbedaan ini tentu saja tidak bisa kita abaikan begitu saja. Kesadaran akan kondisi limbo poskolonial yang dihadapi kedua bangsa dan perbedaan bagaimana mereka merangkumkannya dalam sebuah teks, akan menjadi titik berangkat kita dalam proses dialog imajinatif ini.

\section{A Pause: Amnesia Poskolonial}

Mengikuti metode dari Pui-Lan, kesadaran atas ketidaksesuaian ini mengajak kita untuk berhenti sejenak. Berhenti bukan untuk berdiam diri, tetapi untuk memfokuskan pandangan kita kepada dua hal yang sedang didialogkan dan menelaah ketidaksesuaian yang ada dengan lebih mendalam. Kita telah menyadari di atas bahwa kedua fenomena merupakan gejala dari apa yang disebut oleh Memmi sebagai limbo poskolonial. Maka dengan kesadaran ini, kita diajak untuk berhenti sejenak untuk melihat dan menelaah lebih dalam tentang gejala ini, baik di dalam konteks Indonesia saat ini, maupun di dalam konteks bangsa Israel. Sebagai penuntun bagi kita dalam menelaah 
kedua fenomena dan dalam upaya menemukan sebuah image baru, penulis mengajukan sebuah pertanyaan lanjutan, yaitu: Apa yang menjadi penyebab munculnya gejala limbo poskolonial? Mengapa bangsa Indonesia dan Israel bisa mengalami hal ini?

Untuk membantu menjawab pertanyaan di atas, penulis kembali kepada analisa Memmi, seperti yang dikemukakan oleh Leela Gandhi. Menurutnya, kondisi limbo poskolonial muncul sebagai dampak dari residu dan kenangan akan pengalaman subordinasi ${ }^{51}$. Residu ini bisa ada karena kecenderungan bangsa yang lepas dari penindasan untuk merepresi kenangan penindasan tersebut dan bukan melampauinya. Meminjam penjelasan dari psikoanalisa, represi adalah salah satu defense mechanism -strategi bawah sadar dari ego untuk mengaburkan realita dan mengurangi kecemasan ${ }^{52}$. Untuk melindungi diri dari pengalaman traumatis, kita menekan memori terkait pengalaman tersebut. Pengalaman yang direpsesi ini tidak benar-benar hilang dan biasanya keluar dalam bentuk mimpi dan slip of the tounge. ${ }^{53}$ Proses inilah yang terjadi pada bangsa yang lepas dari penindasan. Leela Gandhi mencatat adanya kecenderungan bangsa yang baru merdeka untuk dengan segera, membentuk sebuah identitas baru yang lepas dari ketertindasan. Kemerdekaan dianggap sebagai momen yang mampu memutus mata rantai penindasan tersebut. Leela Gandhi kembali mengutip Albert Memmi yang menunjukkan bahwa negara paska-kolonial terperdaya oleh anggapan bahwa rancangan dunia baru akan muncul secara ajaib dari reruntuhan kolonialisme, padahal tidaklah demikian adanya.

And the day oppression ceases, the new man is supposed to emerge before our eyes immediately. Now, I do not like to say so, but I must, since decolonisation has demonstrated it: this is not the way it happens. The colonised lives a long time before we see that really new man. ${ }^{54}$

Pembentukan identitas baru ini dianggap sebagai tanda bahwa mereka telah benar-benar lepas dari penindasan, padahal sebenarnya ini hanyalah bentuk represi memori penindasan. Manusia paskapenindasan tidak menghadapi kenangan ketertindasan mereka dan cenderung menganggapnya sebagai sesuatu yang sudah selesai dan perlu ditutup rapat untuk melangkah di dunia baru yang putih bersih,

\footnotetext{
${ }^{51}$ Gandhi, Postcolonial Theory., 7

${ }^{52}$ Sharon Heller, Freud A to Z. (New Jersey: John Wiley \& Sons, Inc., 2005) 67.

53 Ibid., 68.

${ }^{54}$ Albert Memmi, Dominated Man: Notes Toward a Portrait. (London: Orion Press, 1968), 88; seperti dikutip oleh Gandhi, Postcolonial Theory, 6.
} 
seperti sebuah buku baru yang belum pernah ditulisi apa pun. Tanpa disadari upaya 'menutup buku' ini justru membuat residu-residu penindasan yang ada di dalam diri manusia paska-penindasan terus bertahan dan menyebabkan limbo poskolonial, seperti yang dituliskan oleh Leela Gandhi.

The perserve longevity of the colonised is nourished, in part, by persisting colonial hierarchies of knowledge and value which reinforce what Edward Said calls the 'dreadful secondariness'. . . of some peoples and culture. ${ }^{55}$

Kecenderungan ini bisa terlihat dari pengalaman bangsa Indonesia. Awal era reformasi diwarnai dengan berbagai upaya untuk membersihkan segala sesuatu yang "berbau" Orde Baru dan membangun Indonesia dengan tatanan yang baru.

Yang menarik adalah, kita menemukan bahwa proses keluarnya bangsa Israel dari Mesir juga merupakan sebuah proses yang sangat cepat bahkan terburu-buru. Kita bisa menemukannya dalam Kel 12:3941.

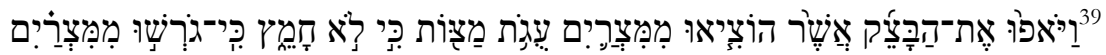

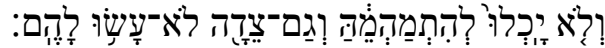

39. Maka mereka membakar adonan yang mereka bawa keluar dari Mesir menjadi roti bundar tidak beragi, karena adonan itu tidak diragi, karena mereka diusir dari Mesir dan tidak dapat berlama-lama dan tidak.juga bisa menyediakan bekal mereka.

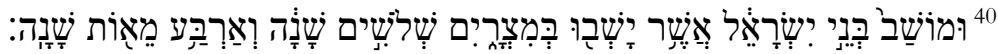
40. Anak-anak Israel berdiam di Mesir selama 430 tahun.

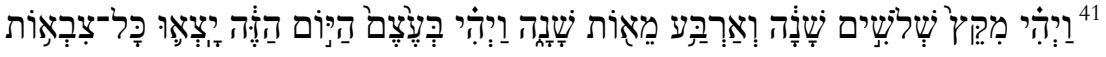 \\ 41. Seduah genap 430 tahun, maka pada bari itu juga selurub pasukean

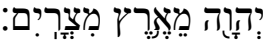 TUHAN keluar dari tanah Mesir.}

Pergantian status mereka dari budak Firaun menjadi bangsa merdeka terjadi hanya dalam satu hari. Ketergesaan ini membuat mereka tidak memiliki waktu untuk menyiapkan bekal yang layak untuk perjalanan, seperti memberikan ragi pada adonan roti mereka.

Hari dimana Firaun membebaskan mereka pergi, dianggap sebagai momen penentu dan pemisah antara status budak dan bangsa

${ }^{55}$ Ibid., 7. 
merdeka. Bahkan sistem penanggalan Israel Kuno dimulai pada bulan, dimana mereka keluar dari Mesir. (Lih. Kel 12:1-2.) Penataan yang demikian ini semakin mempertegas upaya untuk membangun tembok pemisah yang nyata antara masa perbudakan di Mesir dan kehidupan bangsa Israel sebagai bangsa merdeka. Jika bangsa Indonesia berusaha membangun diskontinuitas itu dengan membersihkan pemerintahan dari "antek-antek Soeharto," maka Israel menandainya dengan membentuk sebuah sistem penanggalan yang dimulai dari momentum keluarnya mereka dari Mesir.

Sebagaimana telah dijelaskan di atas, diskontinuitas yang terburu-buru ini tidaklah menghapus memori penindasan. Kenangan dan dampak dari masa-masa penindasan masih ada dan hanya direpresi sedemikian rupa. Hal inilah yang membawa bangsa Indonesia dan Israel ke dalam kondisi limbo paska-penindasan. Ketika Indonesia diperhadapkan pada kenyataan bahwa era Reformasi belum bersih dari $\mathrm{KKN}$, kekecewaan tidak bisa dihindari. Demikian juga dengan Israel. Ketika mereka tidak bisa langsung berada di tanah yang dipenuhi susu dan madu, seperti yang dijanjikan, mereka mulai kecewa dan bersungut-sungut.

\section{Finding A New Image: Residu Kolonial}

Setelah melihat lebih jauh, sekarang kita diajak untuk membaca kembali teks-teks yang ada dengan kesadaran baru. Dengannya, kita berharap bisa menemukan sebuah image baru yang lebih jelas mengenai fenomena foto Soeharto dan teks Keluaran. Di bagian ini, kita akan mencoba melihat teks-teks yang menjadi subjek pembacaan kita dengan kesadaran baru tentang kondisi limbo poskolonial yang dihadapi bangsa Indonesia dan Israel.

Di bagian $A$ consciousness of conflict, kita telah melihat jejak-jejak inferioritas dalam kedua teks. Dalam konteks bangsa Israel, keuntungan jumlah mereka yang banyak bahkan tidak mampu mengalahkan perasaan inferior mereka terhadap Mesir. Frantz Fanon melihat hal yang sama terjadi di Martinik dan Afrika Selatan, sebagai bagian dari daerah koloni Perancis. Jumlah orang kulit putih jauh lebih sedikit dari para penduduk asli, namun hal ini tidak membuat orang kulit putih merasa inferior ataupun seorang kulit hitam merasa superior atas para pendatang kulit putih. Di atas telah dijelaskan bagaimana proses pembentukan inferioritas kelompok kulit hitam terhadap kulit putih menurut Fanon. Inferioritas dan superioritas tidak terkait dengan 
jumlah. Bagi Fanon, inferioritas satu kelompok sangat terkait dengan perasaan superior dari kelompok lain. ${ }^{56}$

Proses inilah yang terjadi di dalam relasi antara Mesir dan Israel. Perbudakan tidak hanya menempatkan Mesir sebagai tuan dalam relasi ekonomi tetapi juga menjadikannya superior sebagai manusia dibandingkan dengan bangsa Israel. Inferioritas inilah yang merupakan presistensi ketidakbebasan bangsa Israel yang mewujud dalam pengejaran Firaun.

Untuk bisa memahami hal, ini penulis mengajak kita untuk kembali ke bagian awal dari kitab Keluaran. Dalam Kel 1:8-11, dinarasikan bagaimana perbudakan bangsa Israel di Mesir dimulai.

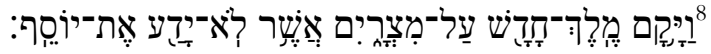

8. Kemudian naiklah seorang raja baru atas Mesir, yang tidak mengetabui tentang Yusuf.

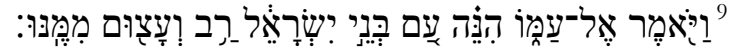

9. dan Ia berkata kepada rakyatnya: "lihatlah! Bangsa Israel itu sangat banyak dan lebib besar jumlabnya dibanding kita.

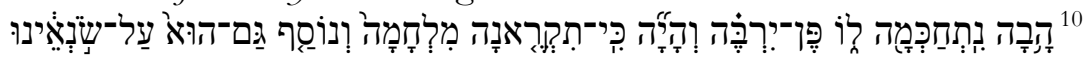

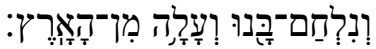

10. Lakukanlah hal yang bijak untuk kita, supaya mereka tidak menjadi semakin banyak dan ketika terjadi perang mereka tidak ikut membenci kita dan berperang melawan kita, lalu menghilang dari tanah ini

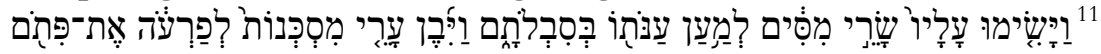

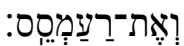

11. Lalu pengawas-pengawas rodi ditempatkan atas mereka untuk menindas (merendabkan) mereka dengan kerja paksa: mereka harus membangun kotakota perbekalan untuk. Firaun, yaitu Pithom dan Raamses.

Menarik untuk dilihat bahwa penindasan terhadap bangsa Israel, dimulai justru karena rasa takut dari pihak Mesir. Karena merasa terancam, Firaun menindas bangsa Israel untuk mengontrol situasi. Meskipun demikian, perasaan terancam ini tetap didasari oleh perasaan superior. Hal ini terlihat dari kata-kata Firaun. Yang paling dikhawatirkan Firaun adalah ketika terjadi perang, bangsa Israel akan bergabung dengan musuh Mesir dan ikut berperang. Firaun tidak menganggap Israel mampu mengambil inisiatif untuk memulai perang. Dan yang dikhawatirkan Firaun adalah setelah perang mereka

${ }^{56}$ Fanon, Black Skin, 69. 
memutuskan untuk pergi dari Mesir. Jika, Firaun benar-benar takut kepada Israel, bukankah seharusnya mereka diusir dari Mesir? Bagi Firaun, kepergian bangsa Israel akan menjadi kerugian bagi bangsanya. Menurut penulis, penjelasan yang memungkinkan pola berpikir Firaun adalah karena bahkan sebelum memulai kerja paksa mereka di Pithom dan Ramses, bangsa Israel adalah orang-orang yang bekerja bagi Mesir dan mereka tidak memiliki posisi sosial, ekonomi dan politik yang tinggi untuk bisa mengambil inisiatif memulai perang. Hal ini dimungkinkan, karena dalam bentuk pemerintahan feodal seperti di Mesir, para penduduk asing memang sering menjadi pekerja kasar atau budak bangsa asli. ${ }^{57}$ Dalam teks bahasa ibrani, Firaun menggunakan kata hl[ yang bisa berarti "menghilang", namun juga bermakna "naik ke atas". Di sini penulis melihat bahwa bagi Firaun, kepergian bangsa Israel dari Mesir bukanlah sekedar masalah migrasi biasa, tetapi juga berarti kenaikan status bagi mereka. Jika bangsa Israel pergi dari Mesir berarti mereka tidak lagi berstatus budak Firaun.

Sebagaimana inferioritas kulit hitam merupakan hasil konstruksi Barat, inferioritas bangsa Israel terhadap Mesir merupakan bentukan sistem yang dimanfaatkan untuk mengontrol kelompokkelompok subordinat. Seperti yang telah dijelaskan di atas, setiap hari sebuah drama penindasan dan subordinasi berlangsung dalam kehidupan masyarakat kolonial hingga membentuk inferioritas. Drama yang serupa berlangsung dalam keseharian bangsa Israel di Mesir sehingga mereka secara kolektif tidak lagi mampu melawan Mesir, meskipun mereka jauh lebih besar jumlahnya. Inferioritas ini telah ada dan telah mereka hidupi selama perbudakan di Mesir.

Dalam kitab Keluaran, kita bisa melihat drama ini berlangsung ketika Musa dan Harun pergi menghadap Firaun dalam Keluaran pasal 5:1-23. Firaun menambah beban kerja bangsa Israel untuk sebagai pertunjukkan kekuasaan dan superioritasnya atas mereka. Setelah mereka mengeluh tentang beban kerja mereka yang bertambah, hal tersebut dikaitkan dengan kedatangan Musa dan Harun ke hadapan Firaun. Pada akhirnya, mereka mengasosiasikan perlawan dan segala upaya untuk mencapai kebebasan dengan penderitaan yang bertambah. Drama ini kembali menegaskan ketidakberdayaan bangsa Israel di hadapan Firaun dan memperdalam perasaan inferior bangsa Israel, sehingga mereka tidak punya pilihan lain, selain menerima bentuk relasi tuan-budak dan kebergantungan mereka pada Mesir.

Proses yang penulis gambarkan ini, serupa dengan gambaran Mannoni tentang orang kulit hitam yang sudah dijelaskan di atas. Hanya saja,

${ }^{57}$ Ronald E. Clements, The Cambridge Bible Commentary on The New English Bible: Exodus (London: Cambridge University Press, 1972), 12. 
Manonni melihatnya sebagai proses alamiah yang muncul karena fakta inferioritas kulit hitam. Di sini, seperti pengamatan Fanon, kita bisa melihat bersama bahwa proses ini merupakan proses interaksi sosial yang disengaja dan dikondisikan oleh pihak Mesir untuk menanamkan inferioritas pada bangsa Israel.

Setelah melihat bagaimana inferioritas bangsa Israel terbentuk, mari kita beralih ke bangsa Indonesia dan melihat bagaimana sistem Orde Baru membangun kebergantungan masyarakat Indonesia kepada Soeharto. Berbeda dengan Mesir yang membangun superioritasnya dengan kekerasan yang terbuka (kerja paksa dan perbudakan), Soeharto menanamkan kekuasaannya atas masyarakat Indonesia dengan membangun sebuah ideologi dan struktur yang memungkinkan munculnya pembenaran akan bentuk-bentuk penindasan yang dilakukannya. Menurut Mudhofir Abdullah, Soeharto berhasil mempertahankan supremasinya atas Indonesia selama lebih dari tiga puluh tahun dengan membangun ideologi Orde Baru, yang ia sebut orbaisme. ${ }^{58}$

Orde Baru menyusun dan merancang sistem nilai yang dibungkus kedok ideologi sebagai cara menaklukkan dan mengendalikan sebuah rezim. Soeharto menyadari bahwa ideologi merupakan hal penting dalam pembantukan way of life manusia Indonesia dan ia diintegrasikan dengan ideologi Pancasila berikut infrastuktur serta suprastruktur pendukungnya. $^{59}$

Sebagai anak Indonesia yang sempat mengenyam pendidikan Sekolah Dasar pada masa Orde Baru, penulis masih mengingat bagaimana buku-buku pelajaran menggambarkan Soeharto sebagai Bapak Pembangunan yang berjasa meningkatkan perekonomian dan infrastruktur daerah-daerah terbelakang di Indonesia. Dalam pelajaran sejarah, Soeharto menjadi pahlawan G30S/PKI 1965 yang berhasil menghentikan upaya PKI untuk menguasai negara. Selain mengontrol isi buku-buku pelajaran, Soeharto juga melakukan indoktrinasi tafsiran Orde Baru terhadap Pancasila melalui kegiatan wajib yang disebut P4 (Pedoman Penghayatan dan Pengamalan Pancasila). Setiap tahunnya, secara rutin diputarkan film dokumenter G30S/PKI yang menempatkan PKI sebagai penjahat yang membunuh para Jenderal TNI. Di lain pihak, pembantaian para anggota PKI yang menyusul

${ }^{58}$ Mudhofir Abdullah, "Soeharto dan Ideologi Orde Baru" dalam Soeharto Sehat, Ed. Asvi Warman Adam, dkk. (Yogyakarta: Galang Press, 2006), 59.

${ }^{59}$ Ibid., 68. 
sesudah kejadian itu tidak diekspos dan dikesankan sebagai kejadian kecil yang tidak terlalu penting dalam catatan sejarah Indonesia.

Selain mengontrol pengetahuan, sejarah dan ideologi, Soeharto juga mengendalikan dunia politik dan memanfaatkan pengaruhnya di dunia militer untuk mempertahankan rezim Orde Baru.

Pada 1969 Golkar dibentuk. Resminya dikatakan bahwa Golkar bukan partai politik - sehingga mempunyai ruang gerak yang lebih luas karena berada di luar aturan-aturan yang membatasi partai politik - namun dalam praktik ia adalah kendaraan politik bagi Soeharto dan Orde Baru-nya. Pada Februari 1980 pemerintah melancarkan program "ABRI Masuk Desa” yang konsekuensinya memberi peluang lebih banyak bagi pihak militer untuk masuk ke dalam dinamika sosial politik masyarakat di tingkat lokal. ${ }^{60}$

Kendali Soeharto di Indonesia mencakup berbagai bidang. Sebagaimana telah diungkapkan di awal artikel ini, Soeharto juga menggunakan kekerasan untuk mengontrol masyarakat. Baskara T. Wardaya menghabiskan 11 halaman untuk mencatat rangkaian kekerasan rezim Orde Baru. ${ }^{61}$ Departemen Penerangan juga hadir untuk mengontrol media dan mengendalikan pemberitaan dan opini masyarakat. Dengan mengendalikan media, suara para intelektual 'bayaran' dan kekerasan 'dibutuhkan', pemerintah telah membungkam pikiran-pikiran tentang oposisi. ${ }^{62}$

Dengan pengendalian yang sedemikan rupa, Soeharto berhasil mengendalikan masyarakat dan menjadi sosok nomor satu di Indonesia selama lebih dari tiga puluh tahun.

Tidak ada bidang yang lolos dari operasi penyusupan dan penanaman orbaisme. Soeharto dan Orba lalu menjadi kekuatan yang mirip Kitab Suci. Siapa pun atau kelompok mana pun yang mencoba melawan atau menentang Soeharto maka dianggap menentang Pancasila dan UUD 1945. Soeharto telah menjelma menjadi Pancasila itu sendiri. Soeharto adalah Pancasila dan Pancasila adalah Soeharto. ${ }^{63}$

Bersamaan dengan naiknya statusnya Soeharto sebagai pahlawan PKI, meningkat pula status pihak militer di mata penduduk Indonesia. Kejadian 1965 misalnya, diangkat menjadi 'kisah sukses' militer dalam

\footnotetext{
${ }^{60}$ Ibid., 31.

${ }^{61}$ Ibid., 27-37.

${ }^{62}$ Ibid., 83.

63 Ibid., 81-82.
} 
menumpas ancaman negara dan membela kesaktian Pancasila. Program 'ABRI Masuk Desa' dan dwifungsi ABRI juga berperan menancapkan pengaruh militer ke berbagai aspek kehidupan masyarakat. Wardaya melihat semua ini membuat kelompok militer dihormati sebagai kelompok istimewa dalam mempertahankan kelangsungan hidup bangsa. ${ }^{64}$ Semua ini berperan dalam menanamkan superioritas Soeharto dan pihak militer atas masyarakat sipil di Indonesia. Selama lebih dari tiga puluh tahun superioritas militer telah merasuk ke dalam kehidupan masyarakat Indonesia. Pada masa Orde Baru, menjadi bagian dari ABRI (Angkatan Bersenjata Republik Indonesia) menempatkan sesorang dalam status sosial yang tinggi, dibandingkan menjadi penduduk sipil.

Demikian uraian tentang proses pembentukan relasi superiorinferior antara Mesir dan Israel, serta Soeharto, pihak militer dan masyarakat umum. Setelah memahami hal ini, penulis hendak mengajak kita kembali kepada penjelasan Mannoni tentang dampak dari inferioritas ini. Bagi Mannoni, pilihan pihak inferior hanyalah bergantung kepada penguasanya atau hidup dalam krisis. Dalam konteks orang kulit hitam, Fanon membahasakan sebagai pilihan ini antara menjadi putih atau menghilang.

Dalam Kel 14:12, bangsa Israel berseru: "Sebab lebih baik bagi kami untuk bekerja pada orang Mesir dari pada mati di padang gurun ini." Di sini bisa kita lihat bahwa pada saat itu, bangsa Israel tidak melihat kemungkinan lain. Pilihan mereka adalah menjadi budak Firaun atau mati di padang gurun. Demikian juga, dalam foto Soeharto, wacana ini menegoisasi pilihan antara kondisi krisis dalam era reformasi dan kembali bergantung kepada sistem militerisme seperti era Orde Baru.

Yang menarik adalah foto Soeharto masih sangat mempengaruhi masyarakat, bahkan disaat Soeharto telah meninggal dunia. Jendral Besar TNI (Purn.) H. M. Soeharto meninggal dunia pada tanggal 27 Januari 2008. Lima tahun setelah beliau meninggal, foto ini beredar dan masih memberikan dampak yang luar biasa pada masyarakat Indonesia. Meskipun secara fisik, sang pemimpin sudah tidak lagi hadir, namun ekspresinya masih mampu membangkitkan memori bangsa Indonesia tentang Orde Baru. Hal serupa bisa kita lihat dalam narasi Keluaran. Setelah lepas dari kejaran Firaun, bangsa Israel melanjutkan perjalanan mereka dan kembali mengalami kesulitan. Secara fisik, mereka telah benar-benar lepas dari Mesir dan Firaun, namun ternyata kesulitan yang mereka hadapi kembali membangkitkan kembali memori mereka terhadap Mesir.

${ }^{64}$ Ibid., 25. 
Dalam Kel 16:1-3, mereka kembali mengingat Mesir ketika mereka sedang kelaparan:

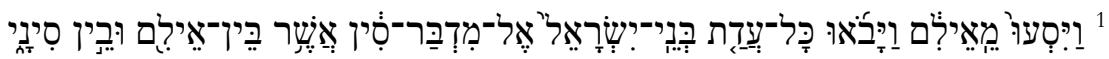

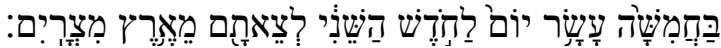

1. Setelah mereka berangkat dari Elim, sampailah seuruh umat Israel di padang gurun Sin, yang terletak antara Elim dan Sinai, pada hari kelima belas bulan kedua sejak mereka keluar dari tanah Mesir.

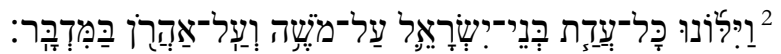

2. Maka bersungut-sungutlah segenap umat Israel kepada Musa dan Harun di padang gurun

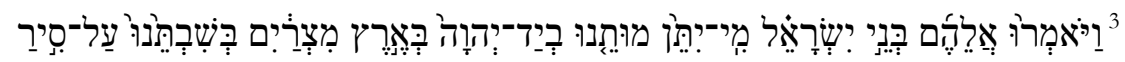

3. dan berkata kepada mereka: "Seandainya kami dibiarkan mati oleh tangan TUHAN di tanah Mesir ketika kami duduk di depan kuali berisi daging dan makan roti sampai kenyang! Karena kalian membawa kami keluar ke padang gurun ini untuk membunuh seluruh umat ini dengan kelaparan.

Sementara, dalam Kel 17:3, krisis yang mereka hadapi adalah kehausan:

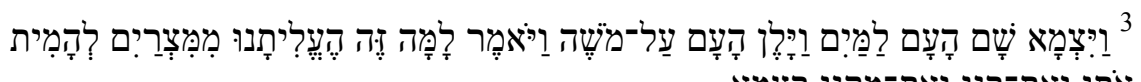

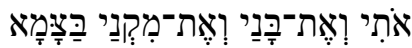

Hauslah bangsa itu akan air di sana dan mulai bersungut-sungut kepada Musa dan berkata: "untuk apa engkau membawa kami keluar dari Mesir, untuk membunub kami, anak-anak kami dan ternak kami dengan kehausan?"

Dalam kedua bagian teks ini, bangsa Israel kembali menghadapi krisis, yaitu kelaparan dan kehausan. Sekali lagi krisis yang mereka alami memperhadapkan mereka pada inferioritas mereka dan pilihan antara kebergantungan dan krisis. Meski tidak lagi berada di bawah perbudakan, Mesir sebagai tuan mereka terus menjadi acuan. Dalam penafsirannya, Ronald E. Clements memandang seruan bangsa Israel sebagai sesuatu yang absurd and illogical, karena makanan budak di Mesir pastilah sedikit dan tidak mencukupi. ${ }^{65}$ Meski demikian, hal yang tidak masuk akal ini terjadi karena inferioritas bangsa Israel. Inferioritas ini, meskipun berakar pada masa penindasan, tidak berhenti bersamaan dengan momen kemerdekaan. Sebagaimana telah dijelaskan di atas ,

${ }^{65}$ Clements, The Cambridge Bible, 98. 
inferioritas ini merupakan residu kolonial yang masih terbawa sampai kepada masa paska penindasan.

Dalam kedua potongan teks ini, terdapat penekanan bahwa yang bersungut-sungut adalah seluruh bangsa, tidak ketinggalan satu

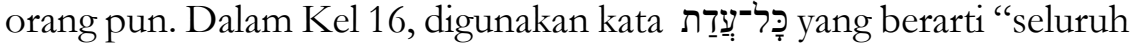
umat", sedangkan dalam pasal 17, subjek yang berbicara diganti menjadi bentuk orang ketiga tunggal. Subjek ini merujuk kepada ha 'am yang berarti "bangsa itu". Kedua teks ini menggambarkan bahwa, keputusasaan dan keinginan untuk kembali ke Mesir dirasakan oleh semua orang, tanpa terkecuali.

Dari ketiga potongan teks Keluaran yang menjadi fokus kita, pertanyaan atau seruan yang terucap selalu terkait dengan tujuan Musa membawa bangsa Israel keluar dari Mesir. Dari ketiga teks ini, bangsa Israel memandang keluarnya mereka dari Mesir hanya akan berakhir dengan kematian. Dalam hal ini, penulis menemukan kemiripan situasi bangsa Israel dengan deskripsi Mannoni.

He begins to demand equality in a way he never before found necessary. The equality he seeks would have been beneficial before he started asking for it, but afterwards it proves inadequate to remedy his ills -for every increase in equality makes the remaining differences seem the more intolerable, for they suddenly appear agonizingly irremovable. This is the road along which (the Malagasy) passes from psychological dependence to psychological inferiority. ${ }^{66}$

Keinginan untuk menjadi setara dengan penguasa, atau menjadi bebas dipandang tidak akan pernah berakhir baik. Bahkan, mendorong orang untuk menuntut kesetaraan sebenarnya merupakan kesalahan dan hanya mengantarkannya pada penderitaan yang tak tertahankan, bahkan kematian. Musa disalahkan karena membawa bangsa Israel keluar dari Mesir dan dengan hal itu, berarti membebaskan mereka dari penindasan. Hal ini juga bisa kita temukan dalam konteks Indonesia. Ketika Indonesia menghadapi krisis, pemerintah era Reformasi juga disalahkan dan dianggap tidak memperbaiki situasi dengan menjatuhkan rezim Orde Baru. Meskipun tidak seekstrim seruan bangsa Israel, bangsa Indonesia juga menunjukkan gejala yang sama. Dalam konteks krisis di Indonesia, foto ini menanggapinya dengan kembali bergantung ke penguasa sebelumnya. Pada bagian $A$ Consciousness of Conflict, kita telah melihat foto Soeharto sebagai sebuah

${ }^{66}$ Fanon, Black Skin, 72-73. 
bacaan negosiasi. Sekarang ini penulis hendak membahas foto Soeharto yang ada di belakang truk, dan disertai tanggapan seseorang.

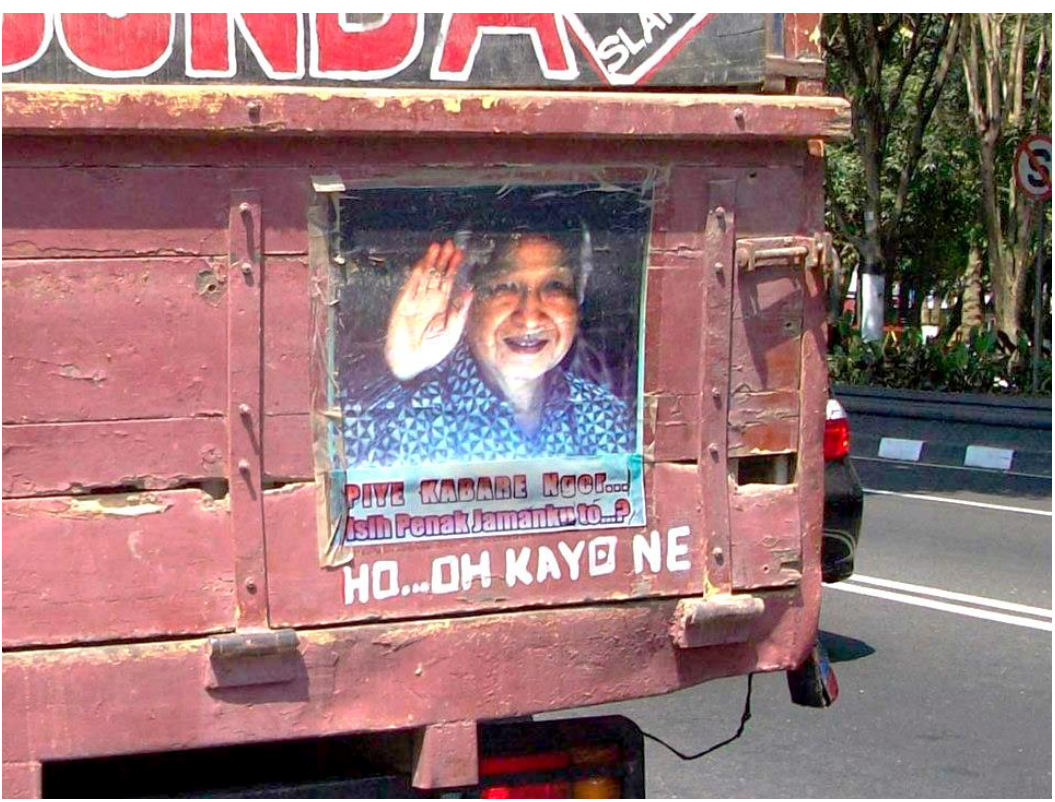

Gambar 6. Foto Soeharto di belakang truk. ${ }^{67}$

Kalimat tanggapan ini berbunyi "Ho..ob kayo ne" yang berarti "iya sepertinya." Ketika tanggapan ini ditulis tepat di bawah foto tersebut, posisi foto ini sebagai bacaan negosiasi bergeser menjadi bacaan dominan. Dalam semiotika media, bacaan dominan adalah bacaan, dimana para pembaca mengambil peran si alamat yang ditawarkan teks dan cara bagaimana si alamat diposisikan dalam kaitannya dengan mitos yang dimiliki teks tersebut. ${ }^{68}$ Perubahan ini tidak hanya terjadi dalam kasus partikular foto di belakang truk ini. Ketika foto ini dijadikan kaos, orang yang membeli dan menggunakan kaos ini berarti mengambil posisi sebagai si alamat yang setuju dengan foto tersebut. Selain itu penggunaan foto ini dalam baliho kampanye partai dan para calon legislatif juga menggeser posisi foto ini dari sekedar negosiasi nilai, menjadi bacaan dominan. Dalam posisi demikian, foto Soeharto memiliki posisi yang sama dengan seruan bangsa Israel di padang gurun.

Sebagaimana telah dibahas di atas, deskripsi Mannoni berangkat dari anggapan bahwa inferioritas bersifat intrinsik. Meski demikian sebagaimana telah kita pelajari di atas, inferioritas merupakan bentukan sistem yang menindas. Oleh karena itu, mengikuti pemikiran

\footnotetext{
67 Nini.ng, Piye Kabare.

68 Thwaites, dkk., Introducing Cultural, 133.
} 
Fanon seharusnya orang tidak diperhadapkan antara inferioritas atau kebergantungan.

\section{The Repatterning of Reality and Interpretation: Membangun Ruang Ketiga}

Yang perlu kita sadari adalah kondisi tarik-menarik ini tidak hanya terjadi sekali, melainkan terus-menerus. Narasi keluaran yang menjadi teks kita merupakan contoh nyata dari hal itu. Bangsa Israel berulang kali harus diperhadapkan dengan kondisi, dimana presistensi ketidakbebasan mengambil bentuk tertentu yang membuat mereka mempertimbangkan kembali untuk kembali ke masa penindasan.

Di dalam bagian pertama dari teks kita, Keluaran 14, peristiwa pengejaran Firaun digambarkan sebagai bagian dari rencana Allah. Jika kita memandang alur penulisan kisah ini, sepertinya Allah sendiri ingin menutup buku perbudakan dengan menunjukkan secara gamblang bahwa kekuasaanNya lebih besar daripada kekuatan Firaun. Sekali lagi, kematian Firaun dan pasukannya di Laut Teberau menjadi momentum besar yang menandakan kemerdekaan bangsa Israel. Mereka bahkan merayakannya dengan nyanyian dan tarian. Namun bahkan tanpa keberadaan Firaun, cengkraman ketidakbebasan masih hidup dalam alam pikir bangsa Israel. Dalam Keluaran 16 dan 17, kondisi tarikmenarik ini mencuat kembali ke permukaan.

Kita harus menyadari bahwa kondisi ketertindasan tidak sertamerta hilang bersama dengan perginya sang penindas. Kondisi psikologis orang-orang yang tertindas setelah sekian lama tidak bisa kita anggap remeh. Perjuangan melawan penindasan tidak berhenti pada sebuah momentum penentu kemerdekaan, melainkan harus diteruskan dalam bentuk perjuangan terus-menerus antara kebebasan dan presistensi ketidakbebasan. Sesudah fenomena foto Soeharto mereda, kita bisa melihat apa yang terjadi dalam Pemilu Presiden 2014. Calon Presiden no.1 saat itu, Jend. Purn. Prabowo berkampanye dengan menjanjikan gaya kepemimpinan yang tegas dan militeristik a la Soeharto. Prabowo mengangkat beberapa tema yang dekat dengan Orde Baru, seperti swasembada pangan dan julukan 'Macan Asia'. Saat itu, banyak masyarakat yang menyambut gembira dan menganggapnya sebagai jalan keluar dari krisis yang sedang dihadapi bangsa Indonesia. Yang menarik dari kedua teks kita adalah bagaimana pertarungan antara kebebasan dan ketidakbebasan ini disikapi. Di dalam Keluaran, kita menemukan bahwa Allah selalu menjadi inisiator dalam menyelesaikan krisis umat Israel sehingga mereka tidak lagi menyerukan ingin kembali ke Mesir (lih. Kel 14:15-18; 16:4-5; 17:5-6). 
Perjuangan melawan perbudakan hanya terjadi di kalangan elit, yaitu Allah sendiri, dengan diwakili oleh Musa dan Harun. Dalam hal ini, bangsa Israel menjadi subjek pasif yang tidak memiliki peran dalam pertarungan tersebut. Atau bahkan bisa dikatakan bahwa Israel menjadi pihak yang presisten tidak bebas dan Allah menjadi pihak yang berjuang membebaskan.

Untuk memahami hal ini dengan lebih baik, penulis mengajak kita untuk melihat potongan teks kita dalam konteks yang lebih luas. Potongan teks yang menjadi fokus pembahasan kita adalah bagian dari narasi besar tentang kisah keluarnya bangsa Israel dari Mesir menuju tanah Kanaan. Dengan menggunakan pendekatan poskolonial, Musa W. Dube membaca keseluruhan kisah ini sebagai narasi pembentukan empire yang diwarnai dengan retorika ideologi anti-conquest. Ideologi anticonquest adalah strategi literatur yang memberikan legitimasi kepada penjajah untuk menguasai tanah asing sambil tetap mempertahankan status tidak bersalah mereka. ${ }^{69}$

Rhetorically speaking, Exodus opens with God's mighty acts of liberation, God's response, God's strongest statement against slavery as a manifestation of imperialism. The narrative invites the implied reader to nod approvingly at God's acts of liberation. Nonetheless, Exodus makes no secret that the 'victimized losers in histroy somehow have the right to become victimizing winners, in turn. ${ }^{70}$

Bagi Dube, kisah penderitaan dan perbudakan bangsa Israel di Mesir serta karya Allah dalam upaya membebaskan mereka adalah pengantar untuk menarik simpati pembaca dan membenarkan invasi bangsa Israel ke tanah Kanaan. Yang tertindas, pada gilirannya berbalik menjadi penindas.

Berangkat dari teori Mannoni dan Fanon, penulis memandang hal ini sebagai jawaban bangsa Israel akan pilihan yang diperhadapkan pada mereka: "turn white or disappear." Tidak seperti para pasien Fanon, dalam narasi ini, bangsa Israel terus menjadi subjek pasif yang tidak pernah menyadari bahwa inferioritasnya adalah bentukan sistem dan pada akhirnya tidak memiliki pilihan untuk mengambil sikap terhadap sistem yang mengungkung mereka. Pada akhirnya, terjebak dalam inferioritas mereka, bangsa Israel memilih untuk menjadi seperti Mesir. Dengan alasan bahwa itu adalah tanah pemberian TUHAN, bangsa

\footnotetext{
${ }^{69}$ Musa W. Dube, Postcolonial Feminist Interpretation of the Bible (St. Louis, MO: Chalice Press, 2000), 60.

70 Ibid.
} 
Israel menginvasi tanah Kanaan, berperang melawan para penduduk asli di tempat itu (bangsa Kanaan, Het, Amori, Feris, Hewi dan Yebus (lih. Kel 3:8). Dalam kitab Yosua pasal 11, kita bisa membaca bagaimana bangsa Israel berperang melawan raja-raja dari bangsabangsa tersebut untuk merebut tanah mereka.

Hal ini sedikit berbeda dengan apa yang kita hadapi dan temukan di Indonesia. Di sini, kita bisa melihat bahwa kondisi tarikmenarik dan juga perjuangan terhadapnya tidak hanya terjadi di kalangan elit, tapi justru melibatkan seluruh masyarakat. Meskipun belum diketahui sumbernya dan bisa dicurigai bahwa foto Soeharto ini disebarkan dengan inisiatif dari kalangan elit yang ingin mengembalikan sturuktur Orde Baru, penyebaran foto Soeharto terjadi di kalangan akar rumput dan menghilang atau dilawan juga oleh kalangan akar rumput dengan berbagai foto-foto yang menjadi wacana oposisi. Walaupun kemungkinan keterlibatan kalangan elit tidak bisa dipungkiri, apa yang berlangsung di akar rumput juga sangat penting.

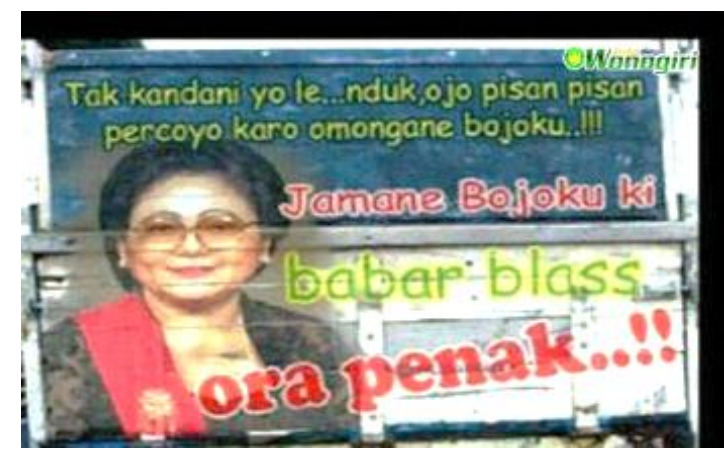

Gambar 5. Foto Ibu Tien Soeharto di belakang truk. ${ }^{71}$

Dalam foto di atas, istri Soeharto, alm. Ibu Tien Soeharto menggantikan posisi Soeharto. Ibu Tien dikenang sebagai sosok ibu negara yang lemah lembut dan memiliki pengaruh besar dalam pemerintahan suaminya. Tentu saja sebagai sosok yang paling dekat dengan Soeharto, Ibu Tien mengetahui dengan baik segala tindakan Soeharto, selama tiga puluh tahun lebih menjadi presiden RI. Bersama dengan foto ini, ada tulisan "tak kandani yo le... nduk, ojo pisan pisan percoyo karo omongane bojoku!!! Jamane bojoku ki babar blas ora penak..!!" yang juga menggunakan bahasa jawa ngoko. Arti tulisan ini kira-kira: Saya

${ }^{71}$ Forum Kaskus, [KOMPAS] Komunitas Piye Kabare Dukung Prabowo

Kembalikan Kejayaan Soeharto, 2014, dalam

http://www.kaskus.co.id/thread/538c9548af07e7420b8b4580/kompaskomunitaspiye-kabare-dukung-prabowo-kembalikan-kejayaan-soeharto/2 diakses tanggal 13 Maret 2015 
nasehatin ya nak, jangan sekali-kali percaya pada perkataan suami saya!!! Zaman suami saya itu sama sekali tidak enak!!”

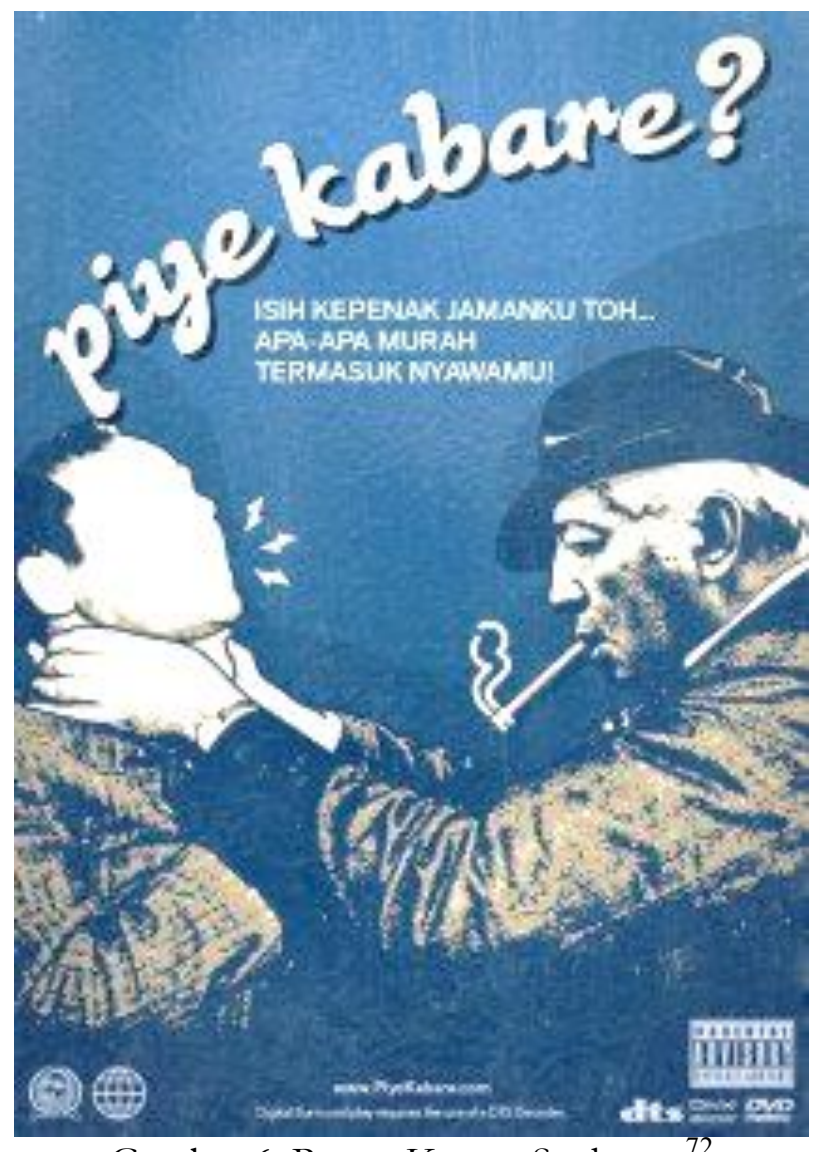

Gambar 6. Poster Kontra Soeharto. ${ }^{72}$

Selain foto Ibu Tien Soeharto, penulis juga menghadirkan foto oposisi yang tetap menggunakan Soeharto sebagai subjek utamanya. Dalam foto yang kedua ini, subjek utama foto tetap Soeharto, tapi dengan ekspresi dan bahasa tubuh yang sangat berbeda. Kata-kata yang digunakan juga merupakan modifikasi dari foto Soeharto yang menjadi fokus pembahasan kita: "Piye kabare? Isih kepenak jamanku toh.. apa-apa murah termasuk nyawamu!". Dalam foto ini, memori tentang kekerasan rezim Soeharto berusaha dibangkitkan kembali. Foto ini merupakan karya seni yang seperti perkataan Bhabha, meninjau ulang masa lalu dan memperbaharuinya, sehingga mampu mempengaruhi

${ }^{72}$ Maulin Niam. Pripun Kabare Mbah (Subarto)? | @31HariMenulis, 2013, dalam https://maulinniam.wordpress.com/2013/06/08/pripun-kabare-mbahsuharto-31harimenulis/ diakses tanggal 13 Maret 2015. 
kondisi saat ini. ${ }^{73}$ Foto ini berusaha membongkar mitos Orde Baru yang aman dan stabil, yang sedang dirindu-rindukan oleh masyarakat, melalui foto Soeharto "piye kabare?", dengan menghadirkan sisi kelam yang selama ini direpresi oleh masyarakat Indonesia.

Kedua foto ini mewakili apa yang dimaksudkan oleh Bhabha sebagai proses re-membering. Kekerasan selama rezim Orde Baru telah direpresi sedemikian rupa dalam memori masyarakat Indonesia. Oleh karena itu, proses-proses seperti ini dibutuhkan untuk menghadirkan kembali memori tersebut agar kita tidak lagi terjebak dalam inferioritas. Jika kita sekarang ini menghadapi krisis, hal itu karena sistem Orde Baru telah merasuk begitu dalam di kehidupan Indonesia dan mencoba melupakannya secara instan tidak akan membantu kita untuk melepaskan diri dari sistem tersebut. Sebaliknya, ketika kita merepresi memori penderitaan tersebut, hal itu akan mengaburkan pertimbangan kita bahkan membuat kita mau kembali ditindas dengan kompensasi keamanan dan kestabilan yang semu.

Lalu, apakah tidak ada upaya re-membering dalam narasi Keluaran? Sebenarnya kita bisa menemukannya dalam perayaan Paskah Yahudi. Di dalam kitab Keluaran, perayaan ini dinstitusikan oleh Allah sendiri dengan tujuan agar umat Israel mengingat bahwa mereka pernah menjadi budak di Mesir dan telah diselamatkan oleh Allah. Di dalam perayaan ini memori penderitaan bangsa Israel dihadirkan kembali melalui simbol-simbol perayaan. Meski demikian, pemaknaan dari perayaan ini lebih berfokus kepada karya penyelamatan Allah dan status bangsa Israel sebagai umat pilihan Allah. Penekanan perayaan Paskah Yahudi adalah karya keselamatan Allah, dimana umat merupakan subyek pasif yang menerima perlakuan dari Allah.

Pada akhirnya, umat Israel dalam simbolisasi perayaan Paskah menjadi umat yang dipilih Allah untuk dibebaskan dari penderitaan. Sebagaimana telah penulis bahas di atas, perjuangan melawan penindasan di dalam narasi Keluaran hanya terjadi di kalangan elit. Karena bangsa Israel hanya menjadi subyek pasif, maka proses penyadaran tentang poskolonialitas mereka tidak terjadi dan mengikuti analisa Fanon, mereka terus terjebak dalam pilihan antara inferioritas atau kebergantungan. Bagi bangsa Israel, tidak ada ruang ketiga. Perayaan Paskah yang seharusnya menjadi proses re-membering, justru menjadi sarana pembentukan identitas baru yang merepresi pengalaman mereka sebagai budak.

Hal ini berbeda bagi bangsa Indonesia. Melalui foto-foto yang menjadi wacana oposisi kita diajak untuk memberi tempat kepada

${ }^{73}$ Bhabha, The Location of Culture, 7. 
proses re-membering. Dengan menghadirkan kembali pengalaman penindasan dengan lebih terbuka, kita sedang menghadirkan ruang ketiga. Bagi penulis, ruang ketiga tidak berhenti pada pembuatan fotofoto oposisi. Ruang ketiga adalah ketika melalui foto-foto tersebut, kita kemudian mulai berani untuk mengupas ulang kisah penindasan selama Orde Baru dan membangun kesadaran akan bahaya hegemoni yang dilakukan Soeharto yang masih mempengaruhi pola piker manusia Indonesia, bahkan sampai saat ini.

Dalam bagian Finding $A$ New Image, penulis telah mencoba menghadirkan kembali dengan lebih jujur pengalaman pada masa Orde Baru dan dampaknya bagi masyarakat Indonesia, baik saat itu maupun sekarang ini. Buku Soeharto Sehat ${ }^{74}$ yang banyak penulis kutip adalah juga sebuah upaya untuk membedah penyakit lama bangsa Indonesia di masa Orde Baru agar kita bias hidup dengan lebih sehat sekarang ini. Hal inilah yang dimaksudkan Bhabha dengan ruang ketiga dan proses re-membering. Ruang ketiga adalah kondisi, dimana masa penindasan dan kemerdekaan tidak lagi dipisahkan secara kaku dengan berbagai upaya diskontinuisasi, yang membuat keduanya seolah-olah merupakan dikotomi yang tidak saling mempengaruhi. Re-membering berarti kesediaan kita untuk melanjutkan hidup bersama dengan berbagai memori penindasan, sehingga di dalam perjalanannya, kita menjadi lebih peka pada isu penindasan dan lebih berhati-hati menyikapinya.

Terkait dengan tema pembahasan kita kali ini, ruang ketiga ada ketika kita mau melihat kembali pengalaman Orde Baru dengan lebih utuh dan tidak serta-merta jatuh pada pilihan ini atau itu (Orde Baru atau era Reformasi sekarang ini). Menurut penulis, sudah saatnya bagi kita untuk membuka kembali buku Orde Baru yang telah lama kita tutup dengan paksa dan mulai mendengarkan lagi berbagai memori tenang Orde Baru dari berbagai sudut pandang.

Dengan demikian tentu saja, kita bisa melihat bahwa kondisi bansga Indonesia sekarang ini masing sangat dipengaruhi oleh apa yang terjadi di masa Orde Baru, atau bahkan masa penjajahan, jika kita melihat jauh ke belakang. Dengan kesadaran demikian dan dengan bekal pengalaman masa lalu kita akan bisa memilih untuk mengupayakan kondisi yang lebih baik, bukan kembali kepada pola lama, tetapi juga bukan bertahan di dalam kondisi krisis sekarang ini.

${ }^{74}$ Asvi Warman Adam, dkk. ed. Soeharto Sehat. 


\section{Tentang Penulis}

Angela Debora Pontororing adalah staff Lembaga Pastoral Terung ne Lumimuut. Ia menyelesaikan program strata satu, Sarjana Sains Teologi, di Fakultas Teologi Universitas Kristen Duta Wacana (UKDW), Yogyakarta pada tahun 2015.

\section{Daftar Pustaka}

Adam, Asvi Warman dkk. ed. Soeharto Sehat. Yogyakarta: Galang Press, 2006.

Ashcroft, Bill dkk. Key Concepts in Post-Colonial Studies. London dan New York: Routledge, 1998.

Bhabha, Homi K. The Location of Culture. London dan New York: Routledge, 1994.

Clements, Ronald E. The Cambridge Bible Commentary on the New English Bible: Exodus. London: Cambridge University Press, 1972.

Dube, Musa W. Postcolonial Feminist Interpretation of the Bible. St. Louis: Chalice Press, 2000.

Fanon, Frantz. Black Skin, White Mask. London: Pluto Press, 2008.

Gandhi, Leela. Postcolonial Theory: A Critical Introduction. St. Leonards: Allen \& Unwin, 1998.

Heller, Sharon. Freud $A$ to $Z$. New Jersey: John Wiley \& Sons, Inc, 2005.

Pearsall, Judy dan Trumble, Bill. The Oxford English Reference Dictionary: Second Edition. Oxford: Oxford University Press, 1996.

Pui-Lan, Kwok. Discovering the Bible in the Non-Biblical World. New York: Orbis Books, 1983. - Postcolonial Imagination and Feminist Theology. Louisville: Westminster John Knox Press, 2005.

Sharpe, Jenny. Ghost of Slavery: A Literary Archaeology of Black Women's lives. Minneapolis: University of Minnesota Press, 2003.

Sugirtharajah, R. S. Exploring Postcolonial Biblical Criticism: History, Method, Practice. Chichester: Wiley-Blackwell, 2012. . The Bible and the Third World: Postcolonial, Colonial and Postcolonial Encounters. Cambridge: Cambridge University Press, 2004.

Thwaites, Tony dkk. Introducing Cultural and Media Studies: Sebuah Pendekatan Semiotik. Yogyakarta: Jalasutra, 2009.

Walzer, Michael. Exodus and Revolution. New York: Basic Books, 1985. 


\section{Sumber Internet}

Forum Kaskus, [KOMPAS] Komunitas Piye Kabare Dukung Prabowo Kembalikan Kejayaan Soeharto, 2014, dalam http://www.kaskus.co.id/thread/538c9548af07e7420b8b458 0/kompaskomunitas-piye-kabare-dukung-prabowokembalikan-kejayaan-soeharto/2 diakses tanggal 13 Maret 2015.

Kelana, Adhy. Stiker Mantan Presiden Soeharto Nempel di Angkot, 2013, dalam

http://www.tribunnews.com/images/regional/view/669201 Lstiker-mantan-presiden-soeharto-nempel-di-angkot\#img diakses tanggal 17 Oktober 2014.

Kristiadi. Pasang Baliho Bergambar Soeharto Mesem, Ini alasan 'Tdeologis' Caleg Golkar, 2013, dalam http://news.detik.com/read/2013/05/21/155421/2251992/ 10/pasang-baliho-bergambar-soeharto-mesem-ini-alasanideologis-caleg-golkar?nd771104bcj diakses tanggal 17 Oktober 2014

Niam, Maulin. Pripun Kabare Mbab (Suharto)? | @31HariMenulis, 2013, dalam https://maulinniam.wordpress.com/2013/06/08/pripunkabare-mbah-suharto-31harimenulis/diakses tanggal 13 Maret 2015

Nini.ng Piye Kabare,..? Isib penak, jamanku to,..?? , 2013, dalam http://niningwell.blogspot.com/2013/05/piye-kabare-isihpenak-jamanku-to.html diakses tanggal 17 Oktober 2014

Nugroho, Andreas. Mengapa 'merindukan' sosok Subarto?, 2013 dalam http://www.bbc.co.uk/indonesia/laporan_khusus/2013/11/ 131125_lapsus_suharto_baju_dan_museum diakses tanggal 20 Oktober 2014.

Winarno, Hery H. Momen-momen Kritis di Balik Lengsernya Soeharto, 2013, dalam http://m.merdeka.com/peristiwa/momenmomen-kritis-di-balik-lengsernya-soeharto.html diakses tanggal 18 Oktober 2014.

Zakaria, Anang. Seniman: Soeharto Piye Kabare Hasil Desain Serius, 2014, dalam http://www.tempo.co/read/news/2014/01/28/078548962/ Seniman-Soeharto-Piye-Kabare-Hasil-Desain-Serius diakses tanggal 12 Oktober 2014. 